BNWL-2019

UC-20

\title{
Management of Nontritium Radioactive Wastes from Fusion Power Plants
}

by

J. D. Kaser

A. K. Postma

D. J. Bradley

September 1976

Prepared for the Energy Research and Development Administration under Contract E(45-1)-1830 
This report was prepared as an account of worix sponsored by the United States Government. Neither the United States nor the Energy Research and Development Administration, nor any of their employees, nor any of their contractors, subcontractors, or their employees, makes any warranty, express or implied, or assumes any legal liability or responsibility for the accuracy, completeness or usefulness of any information, apparatus, product or process disclosed, oi represents that its use would not infringe privately owned rights.

PACIFIC NORTHWEST LABORATORY

operated by

BATTELLE

for the

ENERGY RESEARCH AND DEVELOPMENT ADMINISTRATION

Under Contract EY-76-C-0.6-1830

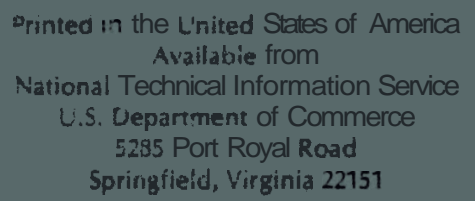

Price: Printed Copy $\$$ "; Microfiche $\$ 300$

\begin{tabular}{l|c} 
Pages & Selling Price \\
$001-025$ & $\$ 4.50$ \\
$026-050$ & 55.00 \\
$051-075$ & $\$ 5.50$ \\
$076-100$ & $\$ 6.00$ \\
$101-125$ & $\$ 6.50$ \\
$126-150$ & $\$ 7.00$ \\
$151-175$ & 57.75 \\
$176-203$ & $\$ 8.50$ \\
$201-225$ & $\$ 8.75$ \\
$226-250$ & $\$ 9.00$ \\
$251-275$ & $\$ 10.00$ \\
$274-300$ & 510.25
\end{tabular}


MANAGEMENT OF NONIRIIIUM RADIOACIIVE WASTES FROM FUSION POWER PLANIS

\footnotetext{
by

J. D. Kaser

A. K. Postma

D. J. Bradley
}

September 1976

Battelle

Pacific Northwest Laboratories

Richland, Washington 99336 


\section{PREFACE}

Fusion reactor technology has developed far enough to expect laboratory demonstration of practical levels of fusion employing the D-T reaction to occur in the early 1980s. Following that demonstration, and depending upon the national priorities for energy from D-T fusion, construction and operation of experimental reactors and demonstration power reactors could occur before the end of this century. Operation of the first commercial power plants could then follow, starting about 2010.

Development and adoption of a new power system eventually will require a description of the environmental effects in an environmental statement providing a comparison to the effects of competitive systems. In anticipation of that statement, an environmental analysis (BNWL-2010) has been prepared for the ERDA Division of Magnetic Fusion Energy. That analysis estimates the environmental effects of constructing and operating D-T fusion reactors as an economically competitive source of electricity in the 21 st century.

The analysis has four primary purposes:

1. To describe the general nature of the environmental effects,

2. To determine current ability to estimate the effects,

3. To determine methods for reducing the effects, and

4. To determine research necessary for increasing capability to define and reduce the effects.

Timely identification of needed research and methods for reducing effects will permit the performance of that research and the revision of conceptual fusion power plant designs before preparation of the program environmental statement. This would improve the quality of the environmental statements and could reduce the estimated adverse environmental effects due to fusion power plants.

The environmental analysis (BNWL-2010) concludes that the following assumed characteristics are the best set for the first operating fusion power plants:

- The D-T fusion reaction

- Large quantities of activation products

- Kilogram quantities of tritium in the plant systems

- Massive reactor structures

- Large lithium inventories

- Large inventories of liquid metals and salts
- Standard electricity generation

- Standard radioactive waste systems

- Large magnetic fields

- A self-contained fuel cycle

- Rural siting

Using these characteristics a reference reactor was analyzed to determine the environmental effects by using available concepts of plant subsystems designs that control interactions with the environment or by assuniption that best current technology would be used in subsystems design.

Because this analysis does not take into account advances in both fusion and waste control technology during the next thirty years, the estimated effects probably are significantly higher than the actual effects will be for the first fusion power plants. The estimated environmental effects should be interpreted only as being the probable upper limit for the actual effects. 
Preparation of the fusion power plant environmental analysis required development and use of specially developed data and analysis methods not used in the preparation of current environmental statements for fossil and fission power plants. These data and analysis requirements are documented in a series of reference topical reports to make this information publicly available and to assure understanding of the basis for the conclusions made in the environmental analysis. These reference topical reports sumarize the state-of-the-art as applicable to preparation of environmental statements for fusion power plants. They present the data and analytical techniques used in the environmental analysis to estimate the interactions with the environment and the resultant environmental effects. This information then was analyzed for adequacy and the need was determined for additional research to assure satisfactory ability to prepare environmental statements for the fusion development program and experimental facilities in the early 1980s. Estimated environmental effects are presented in these reference documents only as necessary to illustrate use of the data and analytical techniques.

This report is one of those reference documents for the environmental analysis. The other documents in this series contain more details of the power plant concepts and the probable environmental effects of fusion power plants with the assumed characteristics listed above. These documents are available through the National Technical Information Service:

An Environmental Analysis of Fusion Power to Determine Related R\&D Needs, BNWL-2010

Review of Fusion Research Program: Historical Summary and Program Projections, BNWL-2011

Fuel Procurement for First Generation Fusion Power Plants, BNWL-2012

Current Fusion Power Plant Design Concepts, BNWL-2013

Reference Comnerical Fusion Power Plants, BNWL-2014

Siting Commercial Fusion Power Plants, BNWL-2015

Materials Availability for Fusion Power Plant Construction, BNWL-2016

Projected Thermodynamic Efficiencies of Fusion Power Plants, BNWL-2017

Tritium Source Terms for Fusion Power Plants, BNWL-2018

Management of Nontritium Radioactive Wastes from Fusion Power Plants, BNWL-2019

Methodology for Estimating Radiation Doses Due to Tritium and Radiocarbon Releases, BNWL-2020

Magnetic Field Considerations in Fusion Power Plant Environs, BNWL-2021

Biological Effects of Tritium Releases from Fusion Power Plants, BNWL-2022

Biological Effects of Activation Prod'ucts and Other Chemicals Released from Fusion Power Plants, BNWL-2023

Safety Review of Conceptual Fusion Power Plants, BNWL-2024

An Investigation of the Transportation Requirements of Fusion Power Plants, BNWL-2025

Considerations of the Social Impact of Fusion Power, BNWL-2026

Environmental Impacts of Nonfusion Power Systems, BNWL-2027

Environmental Cost/Benefit Analysis for Fusion Power Plants, BNWL-2028

Biomagnetic Effects: A Consideration in Fusion Reactor Development, BNWL-1973

An Analysis of Tritium Releases to the Atmosphere by a CTR, BNWL-1938 


\section{SUMARY}

This report identifies nontritium radioactive waste sources for current conceptual fusion reactor designs. Quantities and compositions of the radwaste are estimated for the tokamaks of the University of Wisconsin (UWMAK-I), the Princeton Plasma Physics Laboratory (PPPL), and the Oak Ridge National Laboratory (ORNL); the Reference Theta Pinch Reactor of the Los Alamos Scientific Laboratory (LASL); and the Minimum Activation Blanket of the Brookhaven National Laboratory (BNL).

Disposal of large amounts of radioactive waste appears necessary for fusion reactors. Although the curie ( $\mathrm{C} i$ ) level of the wastes is comparable to that of fission products in fission reactors, the isotopes are less hazardous, and have shorter half-1ives. Therefore radioactivity from fusion power production should pose a smaller risk than radioactivity from fission reactors.

Radioactive waste sources identified for the five reference plants are summarized in Tables 1, 2, 3 , and 4. Specific radwaste treatments or systems had to be assumed to estimate these waste quantities. Future fusion power plant conceptual designs should include radwaste treatment system designs so that assumed designs do not have to be used to assess the environmental effects of the radioactive waste.

TABLE 1 Estimated Solid Waste for Tokamak Reference Plants

\begin{tabular}{|c|c|c|c|c|c|c|}
\hline & \multicolumn{3}{|c|}{ Waste Quantitylyear } & \multicolumn{3}{|c|}{ Waste Curies/year } \\
\hline & UWMAK-I & PPPL & $\mathrm{ORN}$ & & & ORNL \\
\hline Zirconium Foil & $1.1 \times 10^{5} \mathrm{~kg}$ & & 90 MT & $5 \times 10^{6}$ & & $2 \times 10^{7}$ \\
\hline Lithium Oxide & $880 \mathrm{~kg}$ & & $160 \mathrm{~kg}$ & $1.1 \times 10^{5}$ & & $5 \times 10^{4}$ \\
\hline Yttrium Foil & $1900 \mathrm{~kg}$ & $8 M^{3}$ & $1.6 \mathrm{~kg}$ & 1100 & 40 & $5 \times 10^{3}$ \\
\hline Sodium Oxide & $80 \mathrm{~kg}$ & & & 1 & & \\
\hline Charcoal & $4 \times 10^{4} \mathrm{~kg}$ & & & $5 \times 10^{5}$ & & \\
\hline Equipment & $70 \mathrm{M}^{3}$ & $70 \mathrm{M}^{3}$ & $70 \mathrm{~m}^{3}$ & 30 & 60 & 70 \\
\hline Concrete and Bitumen & $330 \mathrm{M}^{3}$ & $330 \mathrm{M}^{3}$ & $330 \mathrm{M}^{3}$ & 80 & 160 & 160 \\
\hline $\mathrm{Hg}$ Amalgam & $1500 \mathrm{~kg}$ & 3 MT & उ MT & $5 \times 10^{5}$ & $7 \times 10^{6}$ & $7 \times 10^{6}$ \\
\hline Flibe Salt & & $30 \mathrm{M}^{3}$ & & & $3.6 \times 10^{7}$ & \\
\hline KF Salt & & $1 \mathrm{MT}$ & & & 4 & \\
\hline $0 \mathrm{il}+$ Adsorbent & & $2 M^{3}$ & $2 M^{3}$ & & $<1$ & $<1$ \\
\hline
\end{tabular}

\section{$\underline{\text { TABLE } 2}$ Solid Wastes for Other Reference Plants}

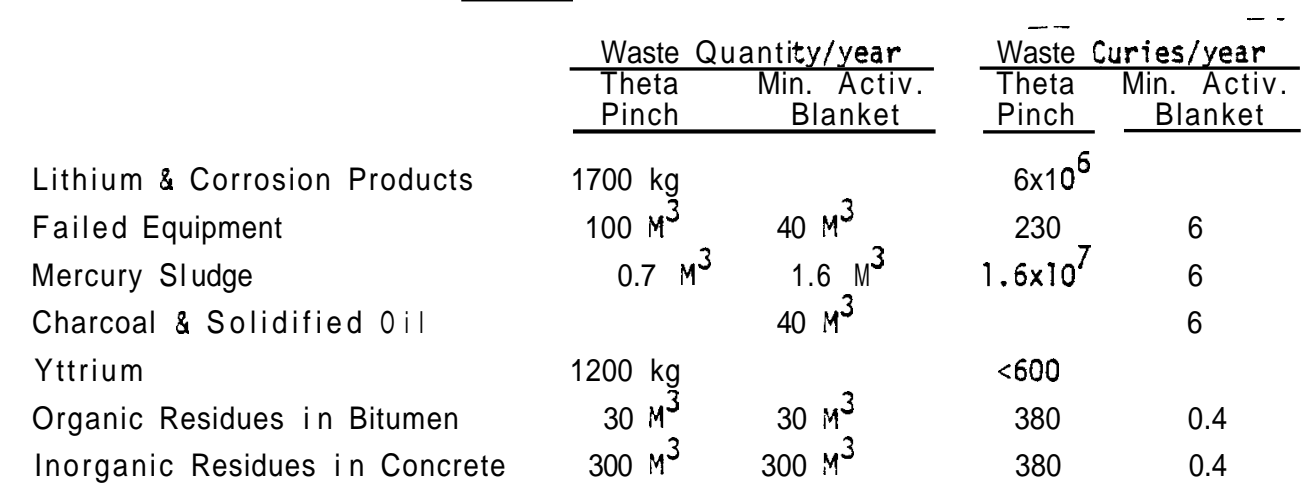

Note: $\mathrm{kg}$ - kilogram, $\mathrm{M}^{3}$ - cubic meter 
$\underline{\text { TABLE } 3}$ Estimated Liquid Waste Sources For Reference Plants

\begin{tabular}{|c|c|c|c|c|}
\hline \multirow[b]{2}{*}{ Reference Plant } & \multirow[b]{2}{*}{ Waste Description } & \multirow[b]{2}{*}{ Gallons/year } & \multicolumn{2}{|c|}{ Curies/year } \\
\hline & & & $\begin{array}{c}\text { After } \\
\text { Treatment } \\
\end{array}$ & Released \\
\hline UWMAK-I & laundry waste water & 100,000 & 400 & $<1$ \\
\hline PPPL Tokamak & laundry waste water & 100,000 & 600 & $<1$ \\
\hline ORNL Tokamak & laundry waste water & 100,000 & 65 & $<1$ \\
\hline Theta Pinch & laundry waste water & 100,000 & 160 & $<1$ \\
\hline Minimum Activation & laundry waste water & 100,000 & 4 & $<1$ \\
\hline
\end{tabular}

TABLE 4 Estimated Gaseous Waste Sources for Reference Plants

\begin{tabular}{|c|c|c|}
\hline Reference Plant & $\underline{\text { Material }}$ & $\underline{\text { Curies Per Year }}$ \\
\hline UMMAKI & ${ }^{14} \mathrm{C}$ & 30 \\
\hline PPL Tokamak & ${ }^{14} \mathrm{C}$ & 30 \\
\hline ORNL Tokamak & -- & 0 \\
\hline Theta Pinch & * & * \\
\hline Minimum Activation & * & * \\
\hline
\end{tabular}

The amounts and composition of solid waste resulting from the replacement of activated blanket structures for several proposed reactor designs were also tabulated. The projected amounts range from 543,000 kilograms $(\mathrm{kg})$ of stainless steel per gigawatt-year (electric] (GWe-yr) for UWMAK-I reactors to $27,000 \mathrm{~kg}$ of niobium alloy per GWe-yr for ORNL Tokamak reactors.

The length of time that the replaced inner wall materials must be stored before the radioactivity decays to any desired level depends on the composition of the inner walls. For example, an 80 percent vanadium-20 percent titanium alloy might take 23 years to decay to innocuous levels, while niobium alloys would require up to $10^{7}$ years.

A process for treating the inner wall structure is described and discussed. The purpose of this process is to convert the inner walls to a form that will not dtsperse readily and can be economically handled and stored. Each process step is discussed in detail. It was concluded that any radioactive waste side streams arising from processing the spent blanket were negligible compared with the radioactive waste resulting from normal operation. Several terminal and temporary storage methods are described and discussed. These methods range from simple land burial and storage in tunnels near ground level to deep burial in geologic formations and sea beds. 


\section{RESEARCH REQUIRED}

Although ample technology is available for safely handling radioactive wastes, the environmental and economic effects of waste handling probably could be reduced by performance of the following research for fusion power plants.

Disposal of Corrosion Products. Additional studies are needed to determine whether to dispose of them as is, or to convert them into a more inert form such as glass.

Recycling of Yttrium and Zirconium. Studies could be made to determine the costbenefit ratio for recycling.

Reclaiming Contaminated Mercury. Additional work would be worthwhile to determine what waste would result and what the final form for this waste should be.

Solidification of Detergent Wastes. It would be beneficial to develop an economical process to concentrate and solidify these voluminous wastes.

Disposition of Contaminated Vacuum Pump Oil. A process needs to be developed for the fixation of pump oil. This process should also satisfactorily immobilize the tritium contained in the oil.

Transport and Deposition of Wall Erosion Material. Knowledge of the transport characteristics of this material would aid in determining activity levels in wastes originating in the vacuum systems and diverter circuits that handle spent plasma.

Activation of Inleaked Air. Additional study is needed to determine the activation of air in and around the reactors that do not have double containment.

The specific benefits from performing this research probably would be a reduction in the amounts of radioactive waste, reduced material use and costs, and lower radiation doses for plant employees during maintenance and waste handling activities. Performance of this research within the next three years would improve substantialy the quality of estimates of environmental effects in the program and experimental facility environmental statements expected to be issued early in the 1980s. More complete data may indicate lower estimates of radiation doses during handling and transportation of radioactive waste.

Current estimates of radioactive waste created in fusion reactors are dependent on the knowledge of corrosion, erosion, and maintenance processes. Since these processes in fusion reactors are not well known, only order-of-magnitude estimates of waste quantities can be made. However, the present systems for collection and disposal of radioactive waste that might be used in fusion reactors are well developed technologies and estimates can be made of the amounts of radioactive waste, other than tritium, routinely released to the environment. Research that increases knowledge of the processes that create the wastes (including tritium) will improve the ability to estimate the amounts.

The use of double containment for fusion reactors would appear to essentially eliminate inleakage of air and the creation of ${ }^{14} \mathrm{C}$ as a gaseous waste. A radwaste system may be developed that would collect ${ }^{14} \mathrm{C}$ and prevent its release. Present methods are adequate for preventing release of radioisotopes in liquid waste but methods for reducing the amount of solid waste can be better investigated when operable fusion reactors are designed and the inner wall materials are defined. 
CONTENTS

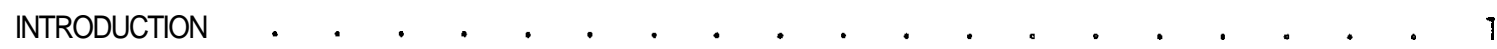

1.0 GENERAL SOURCES OF RADIOACTIVE WASTE . . . . . . . . . . . . . . . . 2

1.1 WASTE SOURCE TERMS FOR UWK - I

1.2 WASTE SOURCE TERMS FOR PPPL TOKAMAK . . . . . . . . . . . . . . 2

1.3 WASTE SOURCE TERMS FOR ORN TOKAMAK . . . . . . . . . . . . 3

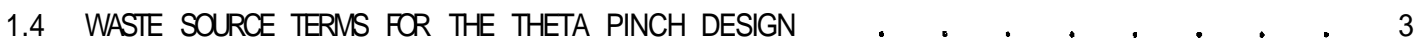

1.5 WASTE SOURCE TERMS FOR THE MINIMUM ACTIVATION BLANKET DESIGN . . . . . $\quad 4$

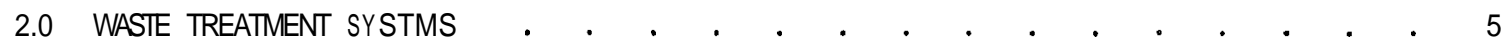

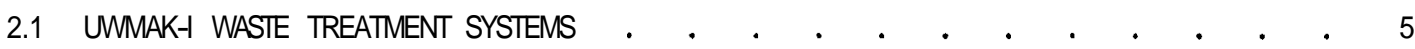

2.1.1 UWK - I Diverter Lithium System Description . 5

2.1.2 UWMAK-I Blanket Lithium System . . . . . . . . . . 7

2.1.3 UWMAK-I Sodium Cleanup System . . . . . . . . . . . . 8

2.1 .4 UWMAK-I Vacuum System . . . . . . . . . . . . . . 9

2.1.5 UWMAK-I Facility and Equipment .Decontamination Processes . 11

2.1.6 UWMAK-I Equipment Replacement and Repair . . . . . . . . 12

2.1.7 UWMAK-I Shieid Cooling System . . . . . . . . . . . 13

2.1.8 Gas Separation System . . . . . . . . . . . . . 14

2.2 PPPL TOKAMAK WASTE TREATMENT SYSTEMS . . . . . . . . . . . . 15

2.2.1 Molten Salt Cleanup Systems . . . . . . . . . . . 15

2.2.2 PPPL Tokamak Vacuum Cleanup System . . . . . . . . . 17

2.2.3 PPPL Tokamak Helium Coolant System • . • . . . . . . 18

2.2.4 PPPL Tokamak Facility and Equipment Decontamination Processes . 20

2.2.5 PPPL Tokamak Equipment Replacement and Repair . . . . . . . 20

2.2.6 PPPL Tokamak Gas Separation System . . . . . . . . . . 21

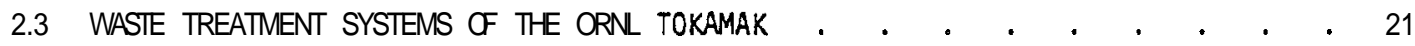

2.3.1 Lithium Cleanup System . . . . . . . . . . . . 21

2.3.2 ORN Tokamak Potassium Cleanup System . . . . . . . . . 22

2.3.3 ORN Tokamak Vacuum System . . . . . . . . . . . . . . 23 
2.3.4 ORN Tokamak Shield Cooling System . . • . . . . . . 24

2.3.5 ORN Tokamak Facility and Equipment Decontamination Processes . . . 24

2.3.6 ORN Tokamak Equipment Replacement and Repair . . . . . . . 25

2.3.7 ORN Tokamak Gas Separation System . . . . . . . . 25

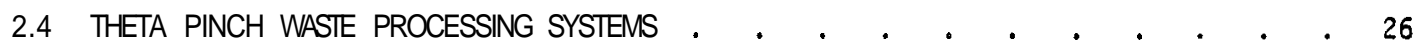

2.4.1 Lithium Processing System . . . . . . . . . . . . 26

2.4.2 Theta Pinch Fuel-Ash Processing System . . . . . . . . . 26

2.4.3 Theta Pinch Vacuum System . . . . . . . . . . . . 27

2.4.4 Theta Pinch Shield Cooling System . . . . . . . . . . 27

2.4.5 Theta Pinch Facility and Equipment Decontamination Processes . . . 27

2.4.6 Theta Pinch Equipment Replacement and Repair . . . . . . . 28

2.5 WASTE TREATMENT SYSTEM FOR MINIMUM ACTIVATION BLANKET DESIGN . . . . . 28

3.0 SUMMARY OF RADIOACTIVE WASTE VOLLMES . . . . . . . . . . . . 30

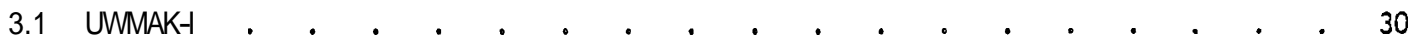

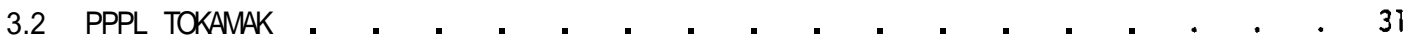

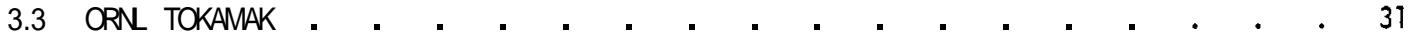

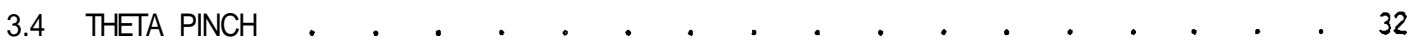

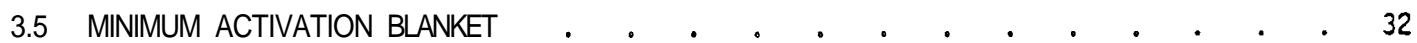

4.0 POTENTIAL STUDY AREAS . . . . . . . . . . . . . . . . . . . 34

5.0 INNER WAL DISPOSAL EFFECTS $. \quad . \quad . \quad . \quad . \quad . \quad . \quad . \quad . \quad . \quad . \quad . \quad . \quad . \quad 36$

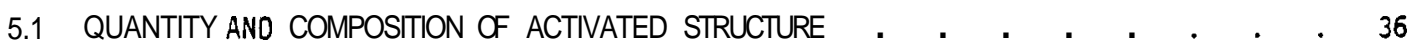

5.2 REQUiRED StORAGe time For ACtivated MATeRIALS . . . . . . . . . . . 36

5.3 TREATMENT OF INNER WAL PRIOR TO STORAGE . . . . . . . . . . . . 40

5.4 StORAGE of ACtIVATED INNER WAL STRUCTURES . . . . . . . . . . . . 42

5.5 RADIOACTIVE EFFLUENTS FOM PROCESSING SPENT INNER WAL STRUCTURES . . . . 44 REFERENCES • • . . DISTRIBUTION . . . . . . . . . . . . . . . . . . . . . . . . . . . 47 


\section{LIST OF FIGURES}

1 Flow Diagram for UMMKł Diverter Lithium System . . . . . . . • . 5

2 Flow Diagram for Treatment of Wastes from UMMAKt Lithium Purification System . 5

3 Flow Diagram for Treatment of Waste from UMMAKA Tritium Extraction System . . . 6

4 Flow Diagram for UMMAKt Blanket Lithium System . . . . . . . . . . $~ .7$

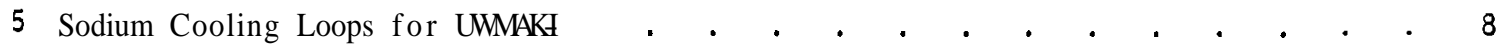

6 Treatment of Waste from Sodium Purification in UMMAKI . . . . . . . . . 9

7 UMMAKI Vacuum System . . . . . . . . . . . . . . . . . . 9

8 Treatment of Vacuum System Waste in UMMAKI . . . . . . . . . . . . $\quad$. 10

9 Equipment Decontamination Processes for UMMAKI . . . . . . . . . . . . 11

10 Treatment of Waste from Decontamination Processes in UMMAKt . . . . . . . . . .

11 Waste from Equipment Repair in UMMAKt . . . . . . . . . . . . 13

12 Shield Cooling System for UMMAKH . • . . . • . . . . . . . . 13

13 Treatment of Waste from Shield Cooling System in UMMAKI . . . . . . . 13

14 Gas Separation System for UMMAKT . • . • . • . . . . . . . 14

15 Treatment of Waste from Gas Purification System for UMMAKt . . . . . . 15

16 Breeder Salt Loop in PPPL Tokamak . . . . . . . . . . . . . . 15

17 Waste Produced by Salt Cleanup System in PPPL Tokamak . . . . . . . . 16

18 Treatment of Waste from TF Decomposition Process in PPPL Tokamak . . . . . . 16

19 Vacuum Cleanup System for PPPL Tokamak . . . . . . . . . . . . . 17

20 Treatment of Vacuum System Waste in PPPL Tokamak . . . . . . . . 17

21 Helium Coolant System in PPPL Tokamak . . . . . . . . . . . . . 18

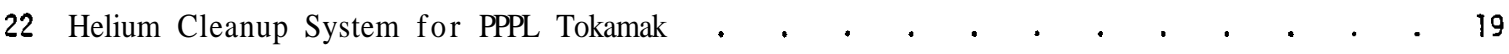

23 Treatment of Waste from Helium Cleanup System of PPPL Tokamak . . . . . . 19

24 Lithium Circuit in ORNL Tokamak . . . . . . . . . . . . . . . . 21

25 Potassium Loop in ORNL Tokamak . . . . . . . . . . . . . . 22

26 Lithium Processing System for Theta Pinch • . . . . . . . . . . 26

27 Blanket Processing for Storage or Disposal . . . . . . . . . . . . . . 40

28 Tunnel for Storage of Radioactive Equipment . . . . . . . . . . . . . 42

29 Typical Module Storage Well (25 Modules per Well) . . . . . . . . . 43 


\section{$\underline{\text { LIST OF TABLES }}$}

1 Estimated Solid Waste for Tokamak Reference Plants . . . . . . 。 . . ix

2 Solid Wastes for Other Reference Plants . . . . . . . . . . . . ix

3 Estimated Liquid Waste Sources for Reference Plants . . . . . . . . . . x

4 Estimated Gaseous Waste Sources for Reference Plants . . .. . . . . . x

5 Waste Quantities Resulting from UWMAK-I Tritium Extraction . 8

6 Nuclide Activity in UWMAK-I Laundry Waste . . • . • . • . • . . 12

7 Gaseous Activation Products Produced from Air in UWMAK-I . . . . . . . 15

8 Waste from Decontamination Processes in PPPL Tokamak . . . . . . . . . . $\quad$. 20

9 Nuclide Activity in PPPL Tokamak . . . • . . . . • . . . . 20

10 Waste from Gas Separation System in PPPL Tokamak. . . . . . . . . . . . 21

11 Gaseous Activation Products Released to Atmosphere by PPPL . . . . . . . . 21

12 Waste Quantities Resulting from Lithium Purification in ORNL Tokamak . . . $\quad$. 22

13 Waste Quantities Resulting from Potassium Purification in ORN Tokamak . . . $\quad 23$

14 Waste Quantities Resulting from Tritium Extraction in ORNL Tokamak . . . . . . 23

15 Waste Resulting from Vacuum System in ORN Plant . . . . . . . . . 23

16 Wastes Resulting from Shield Cooling System in ORL Plant • • . • . . . 24

17 Wastes from Decontamination Processes in ORNL Plant . . . . . . . . . . 24

18 Initial Distribution of Radionuclides from the Activation of Niobium $-1 \%$

Zirconium in ORN Tokamak . . . . . . . . . . . . . . . . 25

19 Wastes from Gas Separation in ORL Plant . . . . . . . . . . . . 25

20 Radwaste from the Fuel-Ash Processing System in Theta Pinch . . • . . . 27

21 Estimated Amounts of Waste from the Vacuum System in Theta Pinch . 27

22 Waste from Shield Cooling System in Theta Pinch . . . . . . . . . 27

23 Waste from Decontamination Processes in Theta Pinch . . . • . . . . . 27

24 Vacuum System Waste fram the Minimum Activation Blanket Reactor . . . . . . 28

25 Nuclide Activity in Minimum Activation Blanket Reactor . . . . . . . . 29

26 Summary of Solid Waste from UWMAK-I . . . . . . . . . . . . . . 30

27 Summary of Liquid Waste from UWMAK-I . . . . . . . . . . . . 30

28 Gaseous Waste Produced by UMMAK-I . . . . . . . . . . . . 30

29 Summary of Solid Waste from PPPL Tokamak . . . . . . . . . . . . 31

30 Summary of Liquid Waste from PPPL Tokamak . . . . . . . . . . . 31

31 Nontritium Gaseous Waste Released from PPPL Tokamak . . . . . . . . . 31

32 Summary of Solid Waste from ORN Tokamak . . . . . . . . . . . 32

33 Summary of Liquid Waste from ORN Tokamak . . . . . . . . . . 32

34 Summary of Waste from the Reference Theta Pinch Reactor . . . . . . . 32

35 Summary of Waste from Minimum Activation Blanket Design . • . . . . . . 33

36 Summary of Projected Radwaste Generation from Various Conceptual Fusion Designs . $\quad 37$

37 Maximum Storage Time for Wall Materials . . . . . . . . . . . . 38

38 Time Required for Activation Products in V-20 Ti to Decay to MPC Levels . 38

39 Time Required for Longer Lived Activation Products in 316 SS to Decay to MPC Levels . 39

40 Time Required for Longer Lived Activation Products in NB-i Zr to Decay to

MPC Levels. . . . . . . . . . . . . . . . . . . . . . 39

Time Required for Longer Lived Activation Products in A1-Mg-Si to Decay . . . . 40
to MPC Levels... 


\section{MANCEMENT OF NONIRIIIUM RADIOACIIVE WASIES FROM FUSION POWER RLANIS}

\section{NIRODUCTION}

The large neutron fluxes in the first generation fusion reactors will activate the reactor structural materials, coolants, and impurities in the coolants and fuel materials. Although many of the radioisotopes will remain in the structures and process streams until they decay to stable isotopes, others will be removed from the process streams by purification equipment, or will escape from the process equipment as a result of leakage.

This report analyzes several fusion powerplant design concepts to determine the types and quantities of radionuclides that must be handled as radioactive waste, the quantities that must be stored as solid waste, and the quantities released as liquid or gaseous effluents.

Tritium is included in the analysis of this section only in those cases where tritium accompanies other radionuclides in solid waste. Tritium releases in gaseous and liquid streams is discussed in BNWL-2018.

This report is divided into five general sections. The first section describes the general sources of radioactive waste for the five fusion reactor design concepts:

$\begin{array}{ll}\text { Tokamak } & \text { University of Wisconsin (UWMAKH) } \\ & \text { Brookhaven National Laboratory (BNL) } \\ & \text { Princeton Plasma Physics Laboratory (PPPL) } \\ & \text { Oak Ridge National Laboratory (ORNL) } \\ \text { Theta Pinch } & \text { Los A1amos Scientific Laboratory (LASL) }\end{array}$

The second section describes the waste treatment systems and estimates the amount of waste routinely created. The third section summarizes the amounts of waste created and the fourth section identifies the additional research efforts 1) necessary for determing the environmental effects of handling the wastes or 2) desirable for identifying methods for reducing the economic and environmental costs due to the radioactive waste. The final section describes the inner wall disposal for fusion reactors. The disposal of the spent reactor inner walls is discussed separately because of the unique handling and storage as compared to fission power plant solid radioactive waste.

Conceptual plant designs have been developed for several approaches to fusion energy production. These conceptual designs provide a framework for identifying radioactive waste disposal sources and treatment schemes that must be reevaluated when the first commercial fusion reactor design is well defined. Changes in reactor design may significantly change the radioactive waste system. Therefore the radwaste system designs and projected waste volumes described here apply only to existing specific fusion concept designs. The amounts of waste and the environmental effects described should be interpreted as a worse case based on current technology. Advances in technology before commercial fusion powerplants are operated could reduce the environmental effects of the radwaste. 


\subsection{GENERAL SOURCES OF RADIOACTIVE WASTE}

Each conceptual power plant design was analyzed to determine the plant subsystems that would be expected to create radioactive waste. This section identifies these subsystems.

\subsection{WASTE SOURCE TERMS FOR UWMAK-I}

In the conceptual design for UWMAK-I, (Badger, 1974) reactor subsystems and operations expected to yield significant quantities of radioactive waste were identified.

Solid Waste Sources. Solid waste contaminated with radioactive materials will be produced in the following systems:

- $\quad$ Lithium Cleanup System (Diverter and Blanket)

- Sodium Cleanup System (Diverter and Blanket)

- Vacuum System

- Facility and Equipment Decontamination Processes

- Equipment Replacement and Repair

- $\quad$ Shield Cooling System

Liquid Waste Sources. Liquid waste will be generated primarily as a result of decontamination operations. Mercury used in vacuum pumps will become contaminated, but will be disposed of as a solid sludge or amalgam rather than as a liquid. Lubricating oil used in the vacuum pumps may be a source of liquid waste, but will be combined with absorbents to produce a solid waste. Liquid waste will come from equipment decontamination solutions and laundry waste water.

Gaseous Waste Sources. Gaseous waste will be generated by inleakage of a ir into the plasma region, and by production of helium from fusion. The gases will be trapped by, and have to be removed from, the vacuum system and the lithium cleanup system.

\subsection{WASTE SOURCE TRMMS FOR PPPL TOKAMAK}

The PPPL Tokamak design (Mills, 1974) has materials and coolants that may present waste sources different from UMMK-I.

Solid Waste Sources. Solid waste contaminated with radioactive materials will be produced by the following systems in the PPPL Tokamak.

- Flibe Cleanup System

- Vacuum System

- Helium Coolant Cleanup System

- Facility and Equipment Decontamination

- Equipment Replacement and Repair 
Liquid Waste Sources. Liquid waste will be generated primarily as a result of decontamination operations. Mercury used in vacuum pumps will become contaminated, but will be disposed of as a solid waste. Liquid waste will come from equipment decontamination solutions and laundry waste water.

Gaseous Waste Sources. Gaseous waste will be generated by inleakage of air into the plasma region, and by production of helium from fusion. These gases will have to be extracted from the vacuum system and from the flibe cleanup system.

\subsection{WASTE SOURCE TERMS FOR ORN TOKAMAK}

Several distinguishing features of the ORN Tokamak (Fraas, 1973) are: 1) inner wall blanket support material made from $\mathrm{Nb}-1 \% \mathrm{Z}$, 2) no diverter protecting the inner wall, 3) plant sized to produce 1000 megawatts-thermal (MWt) power, and 4) heat removed from the Iithium metal blanket by heat exchangers cooled by liquid potassium in the blanket. To simplify comparison of waste from the various powerplant designs, the waste quantities were scaled to those expected for a 5000 MWt plant.

Solid Waste Sources. Solid waste is expected to be generated by the following systems in the ORN Tokamak:

- Lithium Cleanup System

- Potassium Cleanup System

- Vacuum System

- Shield Cooling System

- Facility and Equipment Decontamination

- Equipment Replacement and Repair

Liquid Waste Sources. Liquid waste sources are equipment decontamination solutions and laundry waste water.

Gaseous Waste Sources. There will be no air inleakage to the plasma chamber because of the vacuum building surrounding the toroidal reactor. Pressure in the vacuum building will be kept below $10^{-3}$ torr, hence air inleakage will be reduced to negligible levels.

\subsection{WASTE SOURCE TEMS FOR THE THETA PINCH DESIGN (COULTAS, 1974)}

Although the method for producing plasma and thermonuclear burn is unique, the inner wall hardware and the auxiliary systems resemble those of the tokamak designs. Niobium is used as the first wall material and lithium is used as the primary coolant and breeding material.

Solid Waste Sources. Solid waste is expected to be generated by the following systems in the reference theta pinch reactor:

- Lithium Processing System

- $\quad$ Fuel-ash Processing System

- Vacuum System

- Shield Cooling System 
- Facility and Equipment Decontamination

- Equipment Replacement and Repair

Liquid Waste Sources. The liquid waste sources are the same as the liquid waste sources for the tokamak designs which are equipment decontamination solutions and laundry waste water.

Gaseous Waste Sources. The reference theta pinch design has a secondary vacuum chamber surrounding the plasma chamber to prevent air inleakage which might become activated.

\subsection{WASTE SOURCE TERMS FOR THE MINIMUM ACTIVATION BLANKET DESIGN (POWELL, 1974)}

In this concept the blanket uses an A1-Mg-Si alloy as the structural material. The blanket is designed to fit the UWMAK-I reactor and to operate at the same first wall load, total thermal power, and plasma conditions.

This blanket design has two temperature zones. The cool zone is the aluminum structure bordering the plasma space cooled by a circulating water system designed for zero blowdown. The hotter zone inside the aluminum shells includes graphite, beryllium and solid lithium compounds and is cooled by recirculating helium.

Since the water and helium coolants are noncorrosive and because the water system is designed for zero blowdown, routine removal of activation products from the coolants will probably not be necessary. As a result there should be a very small amount of nontritium radioactive waste from the coolant streams during routine operation.

Activation Products from Inleaking Air. Since the plasma chamber is surrounded by a vacuum, there should be no air leading into the plasma chamber. As a result there should be no activation products from inleaking air. 
This section analyzes each of the waste sources to determine the amounts of waste created.

\subsection{UMMAKI WASIE TREATMENT SYSTEMS}

\subsubsection{UMMAKI Diverter Lithium System Description}

The diverter lithium system is designed to remove impurities from the plasma region. Impurities collected are wall erosion material, inleaked air, helium, and unburned fuel. A flow diagram for the diverter lithium system is shown in Figure 1.

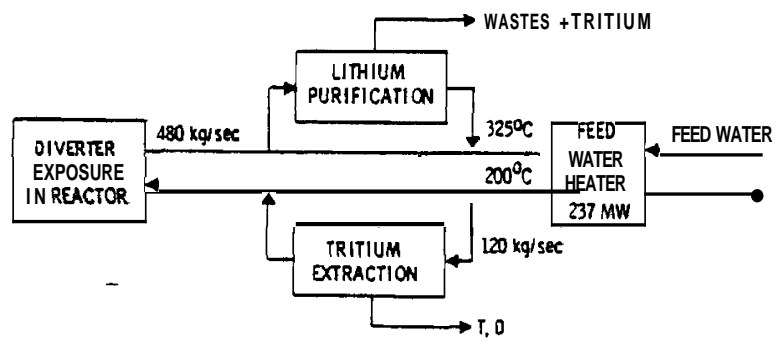

FGURE 1 Flow Diagram for UWK-I Diverter Lithium System

Waste Treatment System for Lithium Purification. The lithium purification system is designed to remove wall erosion materials, dissolved gases, and $L_{i}{ }_{2} \mathrm{O}$. A flow diagram for a proposed process is shown in Figure 2.

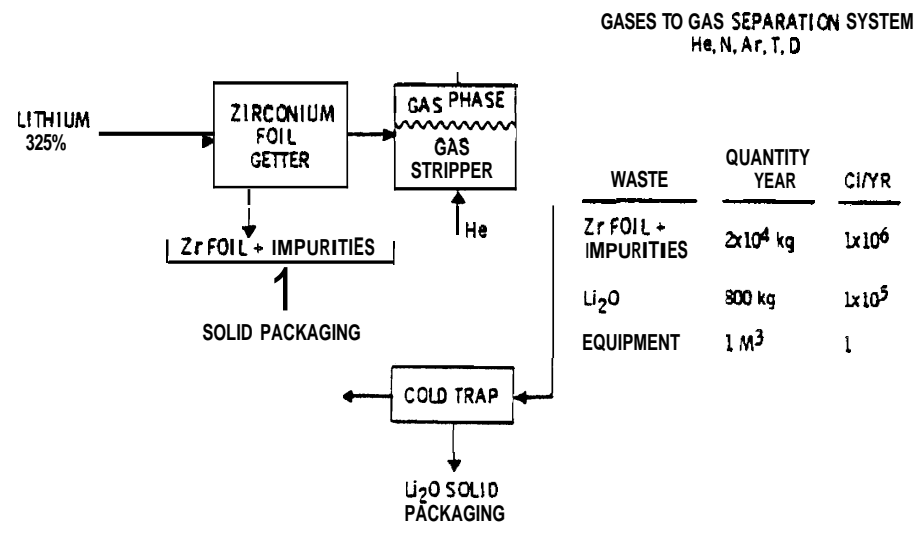

FGURE 2 Flow Diagram for Treatment of Wastes from UMMAK Lithium Purification System 
Zirconium foil getter was proposed for UWMAK-I as a method for trapping corrosion products of stainless steel from lithium. The mass of zirconium foil used in the diverter circuit was calculated from the total zirconium use $\left(10^{5}\right.$ kilograms), accounting for impurity levels in the two lithium loops and assuming a bed life of one year. The activity level of trapped activation products was estimated from the wall erosion rate and the activity level. of corrosion products assuming an equal corrosion rate for all material components. For an erosion rate of 0.07 millimeter per year (mm/yr), some 1600 kilograms $(\mathrm{kg})$ of material would be lost to the plasma region each year. Half of this mass is assumed to be trapped by diverter lithium, and half enters the vacuum system. The specific activity of the eroded wall material was that projected for corrosion products, about 1.5 curies per gram $(\mathrm{C} 1 / \mathrm{g})$.

The mass of lithium oxide collected was estimated on the basis of air inleakage to the plasma chamber. Based on an air inleakage of 0.1 percent per day, and assuming that 50 percent of the oxygen reacted with lithium, $800 \mathrm{~kg}$ of $\mathrm{Li}_{2} \mathrm{O}$ was estimated to be formed yearly. The radioactivity level of this $\mathrm{Li}_{2} \mathrm{O}$ was calculated by assuming that each $\mathrm{kg}$ of oxide carried with it $0.1 \mathrm{~kg}$ of erosion products.

Waste in the form of failed equipment from the lithium purification system was assumed to occupy a volume of no more than 1 cubic meter $\left(\mathrm{m}^{\mathbf{3}}\right)$, and carry with it about 1 gram of erosion products.

Waste Treatment System For Tritium Extraction System. The tritium extraction system shown in Figure 1 is designed to remove tritium and deuterium so that it can be reformed into fuel pellets and reinjected into the plasma. Yttrium bed adsorbers are to be used to trap fuel as a hydride, which is stripped thermally on a periodic basis. A flow diagram for a process to remove fuel and treat waste is shown in Figure 3.

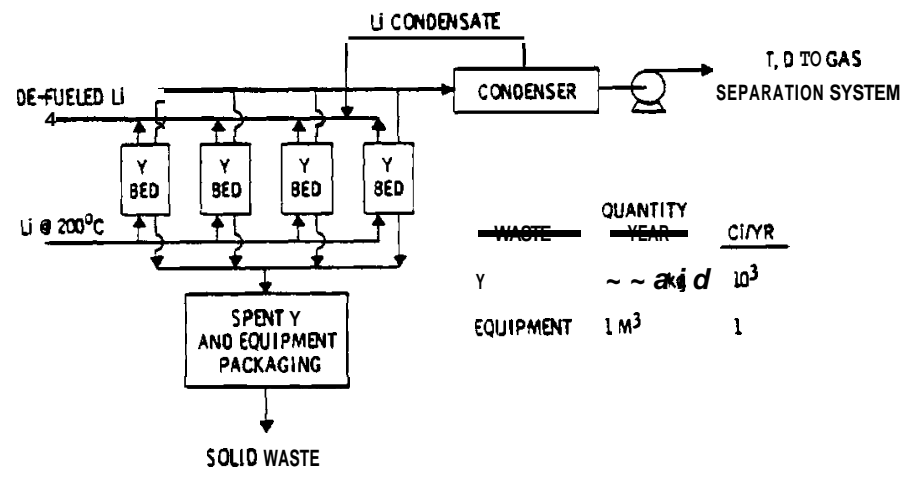

FIGURE 3 Flow Diagram for Treatment of Waste from UWMAK-I Tritium Extraction System

The mass of yttrium generated per year was calculated from the bed masses, assuming a lifetime of 1 year. Adsorption and entrapment of erosion products by the yttrium foil would be expected to be significant. It was postulated that $1 \mathrm{~kg}$ of erosion products would be trapped on the surface of the yttrium foil per year. This is about 0.1 percent of the total erosion products projected for the diverter loop, and would represent some $10^{3}$ curies of activation products. However, the chief contaminent may be tritium. 
The volume of waste represented by failed equipment from the tritium extraction system should be relatively small, and was estimated to occupy mo more than $1 \mathrm{~m}^{3}$. It was assumed that this equipment would be contaminated with 1 gram of erosion products, which would cause an activity level of about 1 curie.

\section{1 .2 UMMAK $\$$ Blanket Lithium System}

The blanket lithium system is designed to remove thermal energy from the reactor and to breed fuel by capture of neutrons which pass through the inner wall. The main waste entering this stream will be corrosion products from the stainless steel flow channels. A flow diagram for the blanket lithium system is shown in Figure 4.

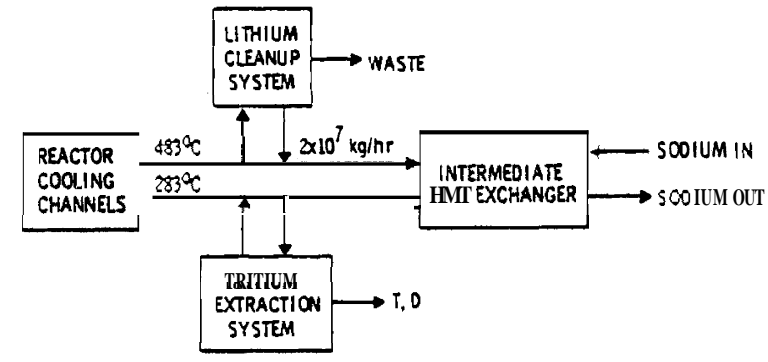

$\underline{\text { BGURE } 4}$ Flow Diagram For UMMAK $\$$ Blanket Lithium System

Waste Treatment System For Lithium Purification. The process to be used to clean lithium and to treat the waste is the same as that shown in Figure 2 for the diverter. The quantities of waste expected are summarized in Table 4.

$\underline{\text { TABLE } 4}$ Waste Quantities Resulting from UMMKł Lithium Purification

\begin{tabular}{|c|c|c|}
\hline Waste & Quantity & Curies Per Year ( $\mathrm{C} / \mathrm{yr})$ \\
\hline 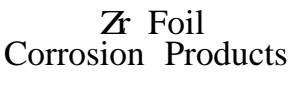 & $80 \mathrm{MT} / \mathrm{yr}$ & $4 \times 10^{6}$ \\
\hline $\mathrm{Li}_{2} \mathrm{O}$ & $80 \mathrm{~kg} / \mathrm{yr}$ & $10^{4}$ \\
\hline Equipment & $1 M^{3}$ & 1 \\
\hline
\end{tabular}

The mass of zirconium foil waste in the blanket lithium purification system was calculated from the bed size assuming a bed life of 1 year. This bed would trap some $2750 \mathrm{~kg}$ of corroded and sputtered products released to the blanket loop each year. These products were estimated to have an activity level of $4 \times 10^{6}$ curies.

Lithium oxide volume was estimated to be 10 percent of the lithium oxide in the diverter loop. A lower quantity is expected because lithium in the blanket loop is not exposed to the plasma. Corrosion product mass equal to 10 percent of the $\mathrm{Li}_{2} \mathrm{O}$ mass was assumed to precipitate out with $\mathrm{Li}_{2} \mathrm{O}$. This mass of corrosion products $(8 \mathrm{~kg} / \mathrm{yr})$ would represent about $10^{4} \mathrm{Ci} / \mathrm{yr}$ of radioactivity. Waste equipment volumes and radioactivity were estimated to be similar to those for the diverter loop. 
Waste Treatment For Tritium Extraction System. The process to be used for blanket tritium removal and waste treatment is substantially the same as that shown in Figure 3 for the diverter system. The quantities of waste expected from this system are summarized in Table 5.

$\underline{\text { TABLE } 5}$ Waste Quantities Resulting from UMMKI Tritium Extraction

$\begin{array}{lllc}\frac{\mathrm{Waste}}{\mathrm{kg} / \mathrm{yr}} & \frac{\mathrm{Cl} / \mathrm{yr}}{180 \mathrm{~kg} / \mathrm{yr}} & 100 \\ \text { Spent Yttrium } & & 1 \mathrm{M}^{3} / \mathrm{yr} & 1\end{array}$

The mass of yttrium foil waste was estimated from the bed size assuming a life of 1 year. This bed is only $1 / 10$ as large as that required for the diverter loop, hence was expected to retain only 10 percent as much corrosion products. Wastes resulting from failed equipment were taken to be the same as in the diverter circuit.

\subsubsection{UMMAKঙ Sodium Cleanup System}

Tho similar sodium cooling systems are used as intermediate heat exchangers between flowing lithium and the steam generator. Such systems exist for both the diverter circuit and for the blanket circuit. Relatively little radioactive waste will result from operation of the sodium loops because the only radiation source term will be leakage of contaminants from the primary lithium circuits. Tritium would be the main radioactive contaminant and its fate is treated in other reports. A flow diagram for the intermediate sodium loops is shown in Figure 5.

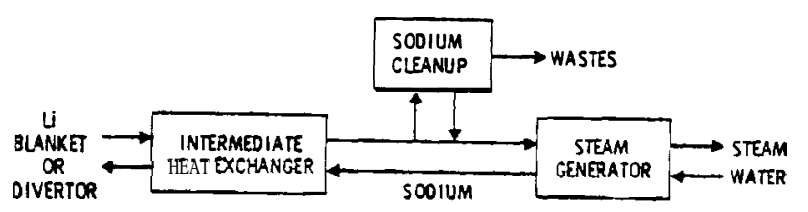

$\underline{\text { FIGURE } 5}$ Sodium Cooling Loops for UMMAKI

Waste Treatment System For Sodium Purification. The sodium purification system uses a zirconium foil to getter impurities, an yttrium bed to extract tritium, a gas trap, and a cold trap. In addition to the low level impurities, replacement of adsorbent beds and equipment would yield low level wastes. A flow diagram for a process for treatment of radioactive waste in the sodium loops is shown in Figure 6.

Waste from the zirconium foil was ratioed from that estimated for the blanket lithium loop. The mass of $\mathrm{Zr}$ foil was taken as 10 percent of that for the lithium loop, or 10 MT/yr. Activity levels would be much lower because the only source of radioactive materials would be leakage from the primary loop. Activity levels in the sodium loop were postulated to be smaller by $10^{4}$ than those in the lithium, yielding about $10^{2}$ curies/year.

The sodium oxide waste mass was chosen the same as that in the lithium, and the activity was taken as $10^{-4}$ times that estimated for $\mathrm{Li}_{2} \mathrm{O}$, or $1 \mathrm{Ci} / \mathrm{yr}$. 


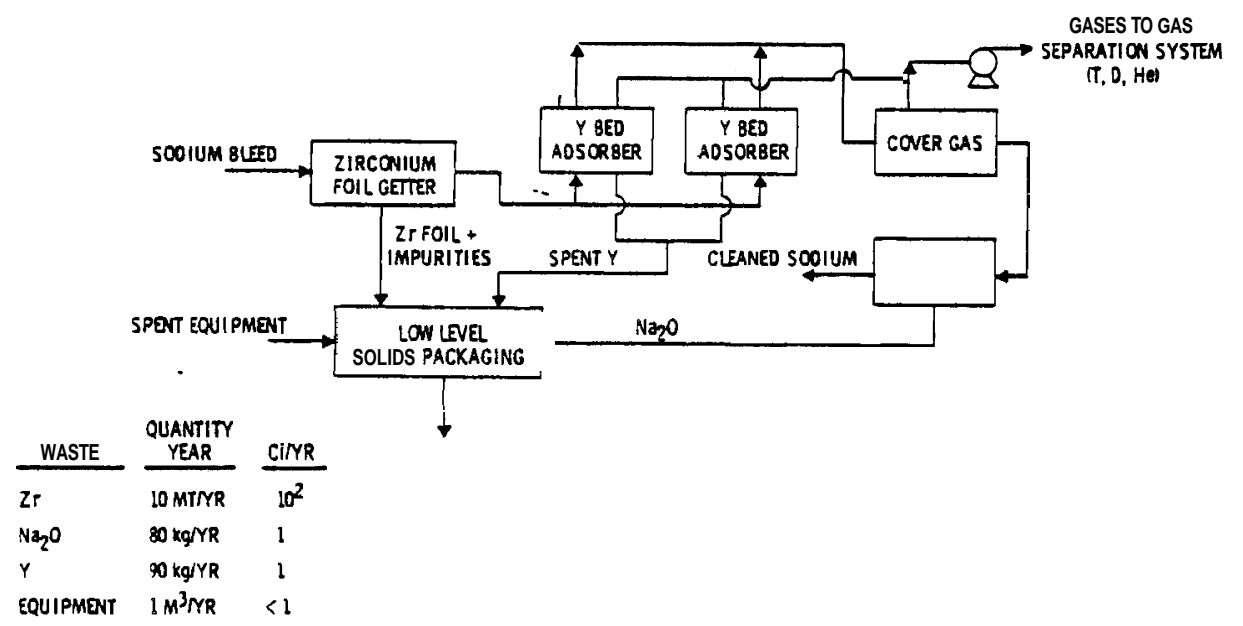

BGURE 6 Treatment of Waste From Sodium Purification in UMMAK

Yttrium waste mass was estimated assuming that the yttrium bed life was 1 year, and the bed size was equal to that specified in the UMMAK design. Activity level on the yttrium bed was assumed to be 1 percent of that on the $\mathrm{Zr}$ bed.

Waste resulting from spent equipment was considered modest, requiring a storage volume of mo more than $1 \mathrm{~m}^{\mathrm{s}} / \mathrm{yr}$. Radioactive contamination' levels would be low for equipment in the sodium loop, and while a specific level has not been estimated, it would probably be less than 1 curie.

\subsubsection{UMMKł Vacum System}

Mrh of the waste generated by fusion power plant operation is trapped by the vacuum system. Major components are identified in Figure 7. The vacuum system is very large and contains many individual components. Most of the wall erosion products entering the vacuum system will be collected by the first vacuum pumps. Inieaked air, unburned fuel, and helium ash would be compressed by this system and piped to the gas separation system.

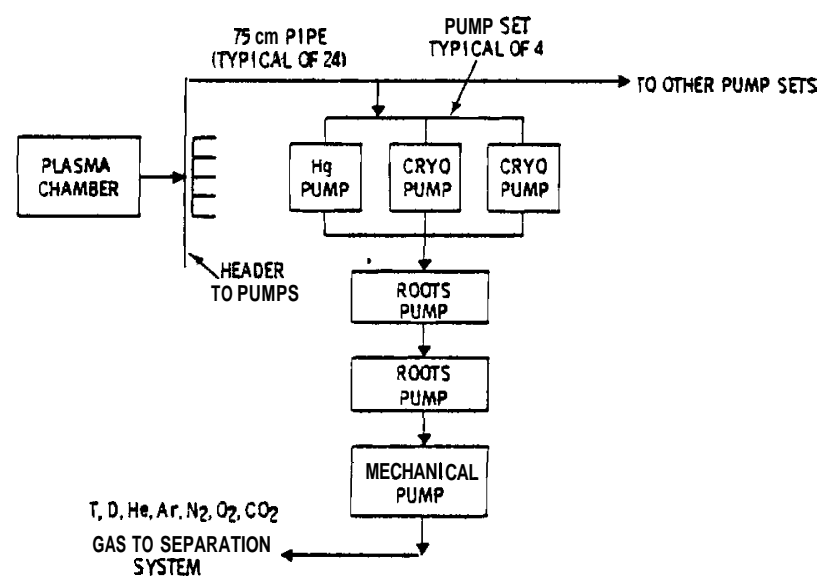

$\underline{\text { BGURE } 7}$ UWMAK-I Vaaum System 
Treatment System For Vacuum Pump Waste. Treatment of waste generated by operation of the vacuum system is shown in Figure 8. Mercury will become contaminated by wall erosion products which enter the vacuum system. The mass of mercury disposed of as waste was equated to the mass of erosion products collected by the diffusion pumps. This mass was obtained by assuming that 50 percent of erosion products entering the vacuum system were trapped by the mercury, and the other 50 percent by the charcoal cryopumps. Thus mercury disposed of as a near-solid sludge would amount to $800 \mathrm{~kg} / \mathrm{yr}$ and would be mixed with $800 \mathrm{~kg} / \mathrm{yr}$ of wall erosion products. The erosion products would contain $5 \times 10^{5} \mathrm{Ci} / \mathrm{yr}$.

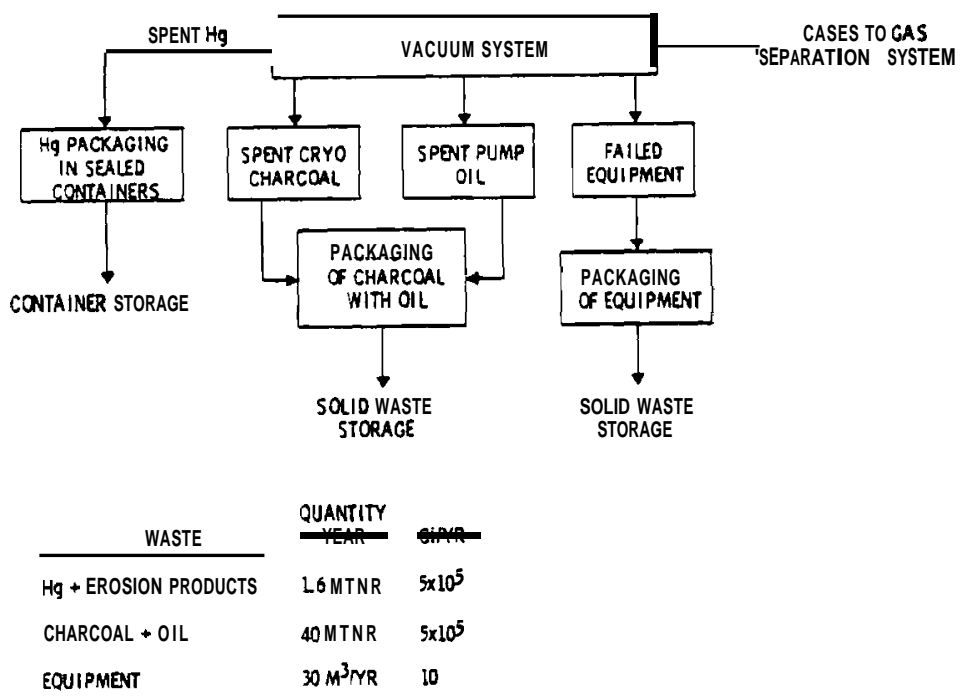

FIGURE 8. Treatment of Vacuum System Waste in UWMAK-I

Charcoal waste volumes were estimated by assuming that each cryopump (192 in number) contained $500 \mathrm{lb}$ of charcoal, and that the charcoal life was 1 year. Vacuum pump oil, primarily from mechanical forepumps, would be adsorbed onto the charcoal. Half of the radioactive material entering the vacuum system was expected to be trapped by the charcoal, and would amount to $5 \times 10^{5}$ Cilyr.

The vacuum system is large and complex and failed equipment might require a disposal volume as large as $30 \mathrm{~m}^{\mathbf{3}} / \mathrm{yr}$, assuming compaction of bulky items. Contamination levels are expected to be comparatively low downstream from the diffusion and cryopumps. An activity level of $10 \mathrm{Ci} / \mathrm{yr}$ (10 grams/yr) was postulated.

Waste resulting from the vacuum system will be relatively high-level because it will contain the neutron activated elements eroded from the first wall. Relatively large quantities of wall erosion products will probably accumulate in the mercury and cryopump charcoal.

$\mathrm{No}$ direct discharge of waste to the environment is expected, because all waste is enclosed in sealed containers and stored as solid waste. Gases will be transported to the gas separation system where inieaked argon, nitrogen, and carbon dioxide will be separated from fuel, held if necessary for decay of activated gases, and then released to the atmosphere. Mercury has been assumed to be disposed of as a sludge when it becomes heavily contaminated. 


\subsubsection{UWMAK-I Facility and Equipment Decontamination Processes}

The equipment used in the primary circuits of the UWMAK-I plant probably will be contaminated with neutron activation products and tritium. Removal of surface contamination will be required for contact maintenance procedures. Decontaniination flushes also may be required to lirnit radiation levels in vacuum pipes. Decontamination processes related to power plant operation are shown in Figure 9.

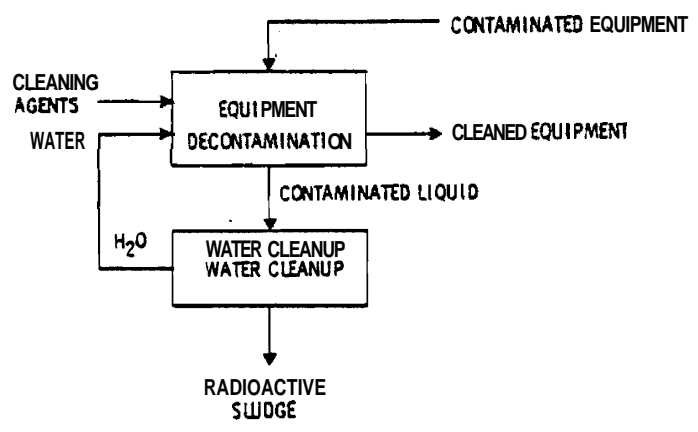

FIGURE 9 Equipment Decontamination Processes for UWMAK-I

Treatment of Waste From Decontamination Processes. Most of the contaminated water from the decontamination processes would be purified and reused. However water containing detergents is difficult to reprocess completely and detergent-containing water might be released as a waste. A conceptual process for treating decontamination waste is presented in Figure 10. Detergent waste is assumed to be present only as low-level laundry waste water which might be released to the environment through dilution with cooling tower blowdown. This laundry water disposal has been used in light water reactors (LWR). Other decontamination solutions are assumed to be free from potent foaming agents. In practice, this forces use of nonfoaming agents in cleaning solutions.

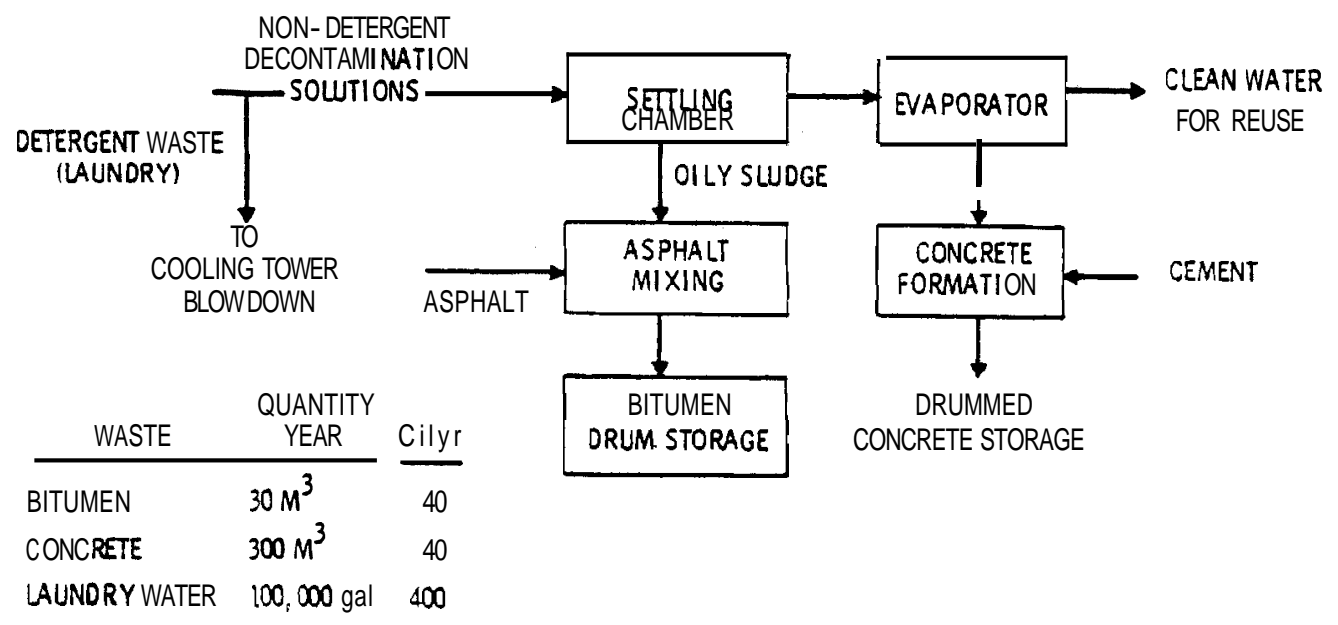

FIGURE 10 Treatment of Waste From Decontamination Processes in UWMAK-I 
The mass of oily sludge was estimated to be of the order of $20 \mathrm{~kg} /$ day for the reference plant. This sludge would be combined with two volumes of asphalt to form three volumes of solidified waste. The yearly waste volume was estimated by assuming 365 days of operation, and a solidified waste density of $750 \mathrm{~kg} / \mathrm{M}^{3}$. Activity level in this sludge could only be assumed, and it was based on an estimated removal of 0.1 grams of erosion/corrosion products per day.

Concentrated inorganic waste liquid from the evaporator would be mixed with Portland cement to form concrete. The volume of this waste was taken as 5 times that typical of a 1000 megawatt-electric (MWe) water reactor. For a LWR, a waste volume of $1000 \mathrm{f} \mathrm{t}^{3} / \mathrm{yr}$ is typical, and extrapolates to an estimated water volume of $150 \mathrm{~m}^{3} / \mathrm{yr}$ for the fusion plant. This volume of water can be solidified by about double the volume of concrete, hence a concrete volume of $300 \mathrm{~m}^{3} / \mathrm{yr}$ is projected.

Laundry waste volumes were scaled on the basis of power level from those for LWRs. The maximum possible activity level associated with discharged laundry water, however, was based on release limits defined in 10 CFR 20. The limit (soluble form) was applied to the cooling tower blowdown stream $(10,000 \mathrm{gpm})$. The important nuclides that could be released in that manner is shown in Table 6.

TABLE 6 Nuclide Activity in UWMAKI Laundry Waste

\begin{tabular}{|c|c|c|}
\hline Nuclide & $\underline{\mathrm{Ci} / \mathrm{V}_{r}}$ & $\underline{\text { Half-Life }}$ \\
\hline $49 v$ & 1 & 331d \\
\hline${ }^{55} \mathrm{Fe}$ & 290 & $2.7 y$ \\
\hline${ }^{58} \mathrm{CO}$ & 60 & 71.38 \\
\hline $57_{\mathrm{Ni}}$ & 2 & $36.0 \mathrm{~h}$ \\
\hline $54 \mathrm{Mn}$ & 50 & $312.5 d$ \\
\hline${ }^{60} \mathrm{Co}$ & 10 & $5.272 y$ \\
\hline Total & 413 & \\
\hline
\end{tabular}

Note: d - days, y - years, h - hours, y - years.

However, if release to a nearby water body would result in an excessive radiation dose the radionuclides probably would be stored, evaporated and eventually buried as solid waste. The water would be recycled for inplant use.

\subsubsection{UWMAK-I Equipment Replacement and Repair}

In addition to inner wall replacement and equipment replacements already listed, equipment having only low-level contamination will be repaired and/or replaced. Equipment items considered are neutral beam accelerators, fuel pellet formation equipment, and gas separation equipment. Figure 11 shows the assumed disposal. 


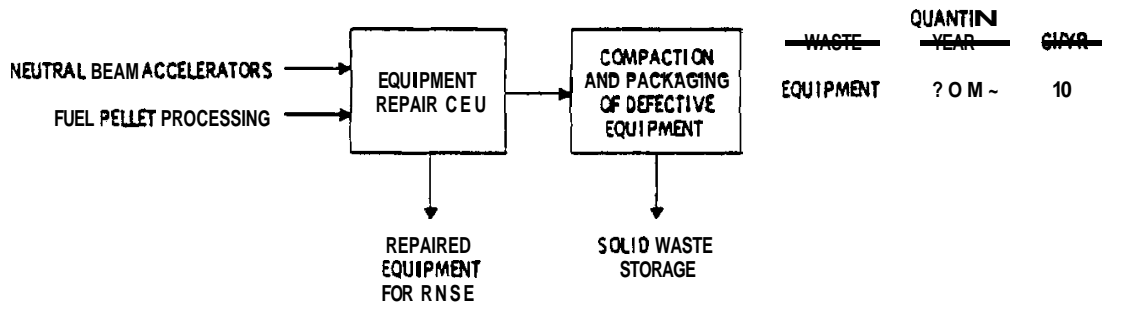

FIGURE 11 Waste From Equipment Repair in UWMAK-I

\subsubsection{UWMAK-I Shield Cooling System}

In the UMMAK- design, the neutron shield is cooled by flowing helium. Only low-level contamination of this circuit would be expected, primarily because of diffusion of tritium into the helium stream. The shield cooling system is shown Figure 12.

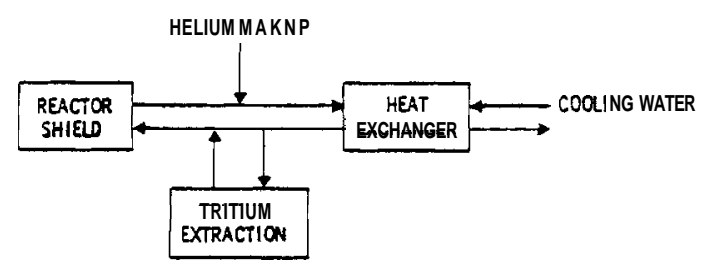

FIGURE 12 Shield Cooling System for UWMAK-I

Waste Treatment For Shield Cooling System. Tritium extraction from flowing helium is expected to be done by yttrium bed adsorbers. Particulate contamination of the helium has been assumed to be negligible, and no filters will be required. Figure 13 presents a diagram of the proposed waste treatment methods.

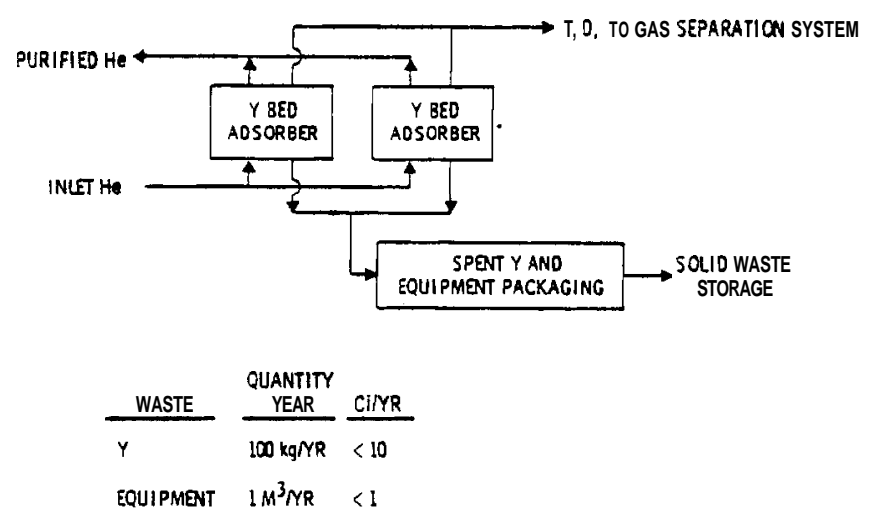

FIGURE 13 Treatment of Waste From Shield Cooling System in UWMAK- 
An yttrium bed adsorber, sized the same as that required for the sodium system, will generate $100 \mathrm{~kg} / \mathrm{yr}$ of waste. Activity levels should be low. However, since some neutron sputtering of activation products into the helium coolant may be expected, some deposition of radioactive materials on the yttrium beds wi11 occur. Such deposition was estimated to amount to no more than 10 grams/yr, with an attendant activity level of about $10 \mathrm{ci} / \mathrm{yr}$.

Equipment needs for the helium circuit are relatively modest, and the storage volume for spent equipment was estimated to be no more than $1 \mathrm{~m} / \mathrm{yr}$. Contamination levels would be low, indicated as $<1 \mathrm{Ci} / \mathrm{yr}$.

\subsubsection{Gas Separation System}

A gas purification system is provided to separate unburned fuel (tritium and deuterium) from ash (helium) and gases which leak into the reactor $\left(\mathrm{N}_{2}, \mathrm{Ar}, \mathrm{CO}_{2}, \mathrm{O}_{2}\right)$. This separation system must be highly efficient to reclaim unburned fuel and to prevent release of tritium to the atmosphere.

Description of Gas Separation System. A conceptual design for a gas purification system is shown in Figure 14. Gettering beds using $Y$ foil are used on the nonfuel streams to trap residual tritium. A holdup chamber is provided to allow decay of short-lived isotopes of nitrogen and argon.

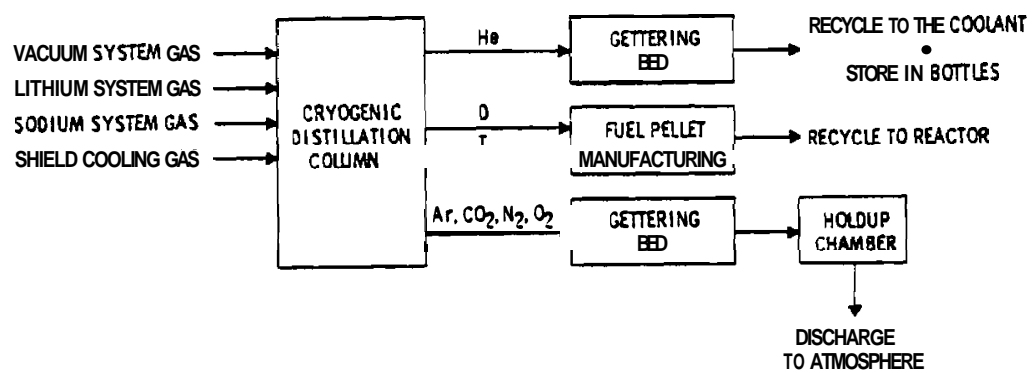

FIGURE 14 Gas Separation System for UWMAK-I

Treatment of Wastes From Gas Separation System. Waste resulting from operation of the gas purification system is treated as shown in Figure 15. The gases discharged to the atmosphere are the most important waste emanating from the cryogenic still because they contribute directly to calculated offsite radiation exposures.

The activity level at the end of 1 day is dominated by $13 \mathrm{~N}$ and amounts to a sizable number of curies (Table 7). Additional two-day holdup would eliminate almost all activity except the ${ }^{14} \mathrm{C}$ and result in curie levels that are modest compared to noble gases emitted from LWRs. Some of this holdup time would be provided by the cryopumps in the vacuum system. 


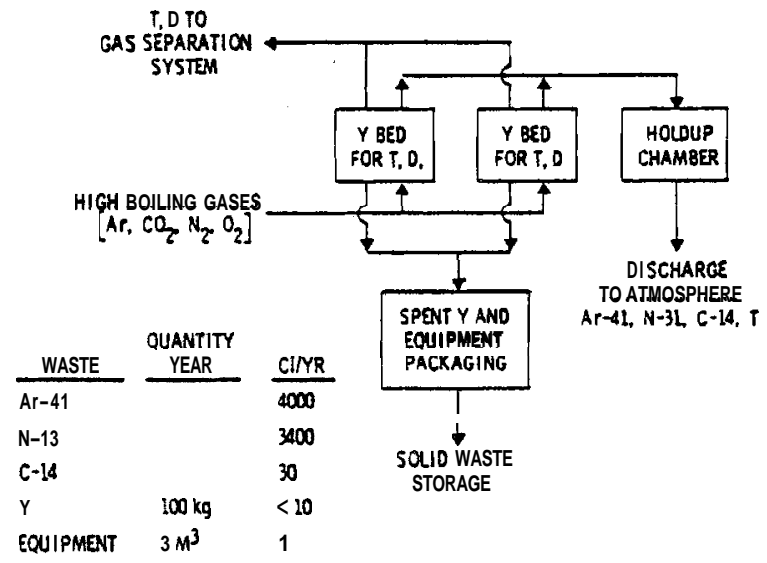

FIGURE 15 Treatment of Waste From Gas Purification System for UWMAK-I

$\underline{\text { TABLE } 7}$ Gaseous Activation Products Produced From Air in UMMAK-

$\begin{array}{cccccc}\begin{array}{c}\text { Product } \\ \text { Nuclide }\end{array} & \begin{array}{c}\text { Production Rate } \\ \text { Curies/day }\end{array} & \begin{array}{c}\text { Activity At End } \\ \text { of 1 Day. Curies }\end{array} & \begin{array}{c}\text { Activity After } 2 \mathrm{hr} \\ \text { Hold-Up, Curies }\end{array} & \begin{array}{c}\text { Hold-Up Time To } \\ \text { Reduce To } 1 \mathrm{mCi}\end{array} \\ \mathrm{N}-13 & 4 \times 10^{6} & 4 \times 10^{4} & & 9.4 & \\ \mathrm{~N}-16 & 3 \times 10^{3} & 3 \times 10^{-2} & & 0 & \\ \mathrm{C}-14 & 8 \times 10^{-2} & 8 \times 10^{-2} & & 0.08 & 36 \mathrm{mec} \\ \mathrm{Ar}-41 & 2 \times 10^{2} & 2 \times 10^{1} & 11 & 36,000 \mathrm{y} \mathrm{r} \\ & & & & 27 \mathrm{hr}\end{array}$

\subsection{PPPL TOKAMAK WASTE TREATMENT SYSTEMS}

\subsubsection{Molten Salt Cleanup Systems}

Molten salt (a eutectic of $53.1 \% \mathrm{BeF}_{2}$ and $46.9 \%$ Lif), is circulated through the blanket section of the reactor to accomplish breeding of tritium from lithium. The salt is relatively corrosive, and dissolves appreciable quantities of the PE-16 structural material, contaminating the salt. Tritium must be removed from the molten salt so that it can be injected into the plasma. A diagram of the molten salt (flibe) system is shown in Figure 16.

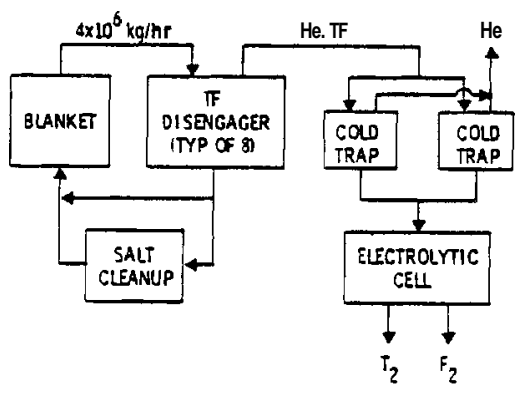

FIGURE 16 Breeder Salt Loop in PPPL Tokamak 
Waste Treatment System For Salt Cleanup. The main source of waste from the salt loop is the salt cleanup system. A specific process for removing corrosion products from the flibe salt was not proposed in the PPPL design, hence one was selected. One possible separation technique would be fractional crystallization. This approach would be possible if the chromium salt formed from corrosion led to a noneutectic salt mixture. An appreciable quantity of flibe would also be removed with the chromium, iron, and nickel salt. Further treatment of the waste salt could be done by aqueous processing if it was necessary to reclaim lithium, beryllium, or fluorine. Waste generated in a salt cleanup system is shown in Figure 17.

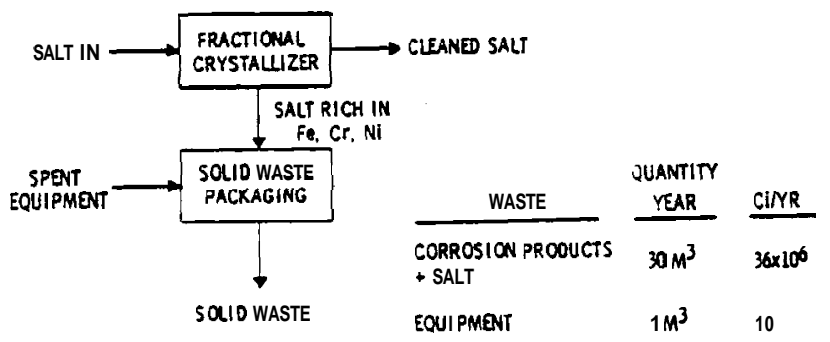

BGURE 17 Waste Produced by Salt Cleanup System in PPPL Tokamak

The volume of contaminated salt was projected on the basis of the estimated corrosion product mass $\left(12.6 \mathrm{MT} / \mathrm{Yr}_{\mathrm{r}}\right)$ and an assumption that each mass of corrosion products would be mixed with three masses of flibe. The density of the waste was taken equal to the salt density. The radioactivity level was projected in the design document. The crystallization process is fairly simple from an equipment standpoint, hence spent equipment disposal was assumed to require no more than $1 \mathrm{~m}^{3} /$ Year. The activity level of the spent equipment was calculated assuming contamination by 10 grams of the salt rich in corrosion products.

Waste Treatment System For TF Decomposition System. TF is decomposed in an electrolytic cell into $T_{2}$ and $F_{2}$. Waste will result from contamination of the $K F$ bath, and from failed equipment disposal. Fluorine gas is a potential problem because of tritium contamination, but it is assumed that $F_{2}$ evolved from the cell will be recycled to the salt. The quantity of $F_{2}$ is very small compared to the salt mass, and would tend to make up for $\mathrm{F}$ removed with corrosion products. Waste generated in the TF decomposition process is summarized in Figure 18.

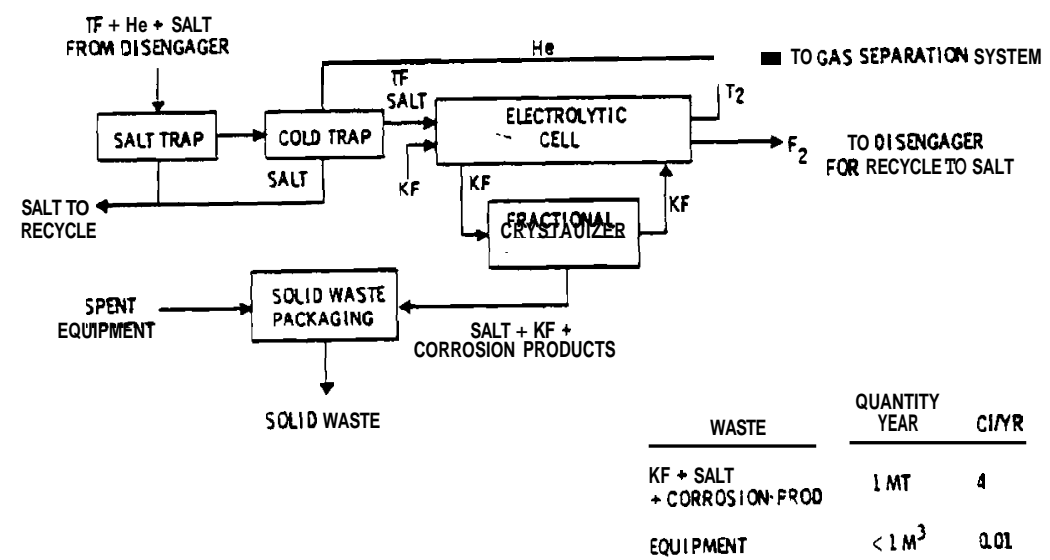

HGURE 18 Treatment of Waste From TF Decomposition Process in PPPL Tokamak 


\subsubsection{PPPL Tokamak Vacuum Cleanup System}

The vacuum system in the PPPL plant is used to evacuate the plasma chamber between burns and to exhaust the diverter outflow during the burn cycle. The required pumping speed of $6.7 \times 10^{5}$ iiters/sec is set by the requirement that the plasma chamber be evacuated in 30 seconds. Major components of the PPPL vacuum system are shown in Figure 19. Not included are special forepumps used to pump down from atmospheric pressure. These pumps would be used very little and would not be expected to generate important quantities of radioactive waste. This vacuum system makes more extensive use of mercury pumps than did the UWMAK-I system, and for this reason disposal of mercury waste will require more effort. Argon gas is added in the PPPL system as a radiant, and hence will have to be exhausted through the vacuum system.

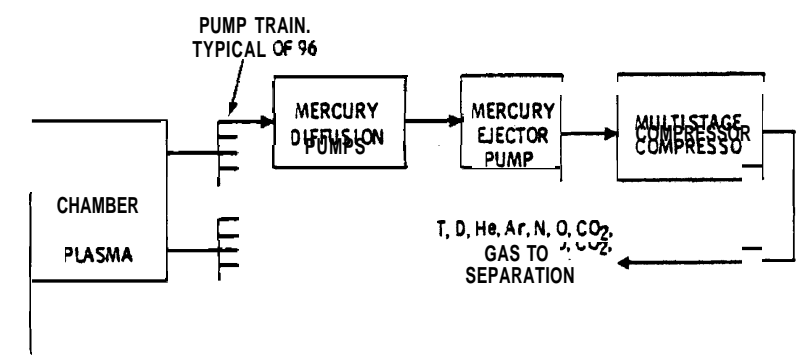

$\underline{\text { FGURE } 19}$ Vacuum Cleanup System for PPPL Tokamak

Part of the argon, and ail of the nitrogen, oxygen, and carbon dioxide indicated as effluents result from inleakage of air. Helium is ash from the fusion reaction, and tritium and deuterium are unburned fuel. Inleakage into the vacuum system gives rise to most of the gaseous waste from the PPPL plant.

Treatment System For Vacuum System Waste. Treatment of waste generated by the vacuum system is shown in Figure 20.

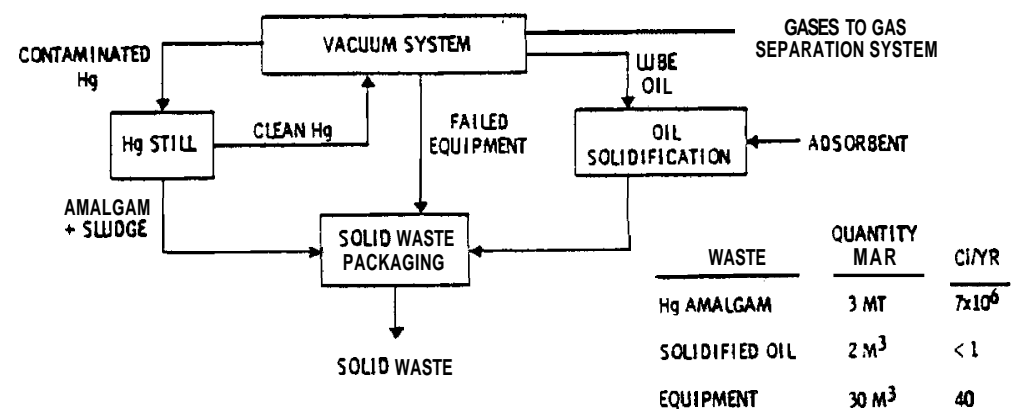

FGURE 20 Treatment of Vacuum System Waste in PPPL Tokamak

Mercury pumps would trap almost all of the wall erosion products carried in the diverter stream. The solidified amalgam and sludge was assumed to carry a mass of mercury equal to the mass of eroded wall material. Basing the wall erosion mass on the value computed for UWMAK-I, the total mass of amalgam and sludge was estimated to amount to 3 metric tons per year (MT/Yr). The activity level for this waste was calculated by multiplying the mass of eroded wall material by the specific activity $(4 \mathrm{Cj} / \mathrm{g}$ ) estimated from data in the PPPL design document. This activity is for nuclides with half-lives longer than 1 year. 
Waste resulting from disposal of lubrication oil was quantified by assuming that 1 gallon of oil would be required per year for each of the 96 multistage compressors, and that the adsorbent volume was four times the oil volume. This modest oil volume is based on the assumption that high quality recirculating oil filter systems would be used on the compressors, obviating the need for larger volumes of oil. Activity levels in the oil would be very low, and are simply indicated as less than 1 curie. Tritium contamination was not considered.

Waste volume from spent equipment was taken to be the same as that estimated for the UWMAK-I system. Activity level was estimated from an assumed contamination due to 10 grams of erosion products.

\subsubsection{PPPL Tokamak Helium Coolant System}

The helium coolant system (Figure 21) transmits all thermal energy from the reactor to the steam generators. This is a huge system involving a flow of more than 1 million cfm of helium at 50 atm.

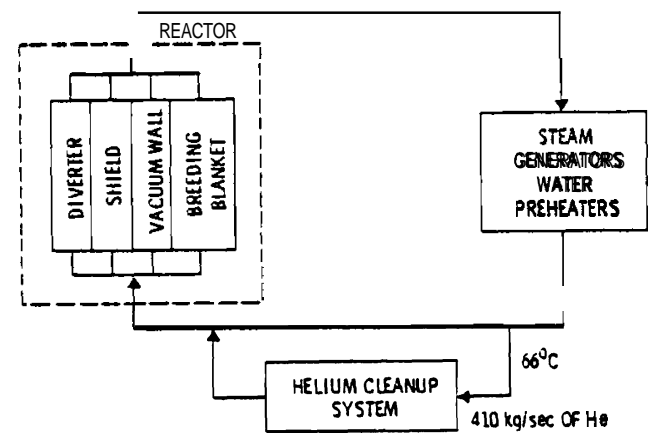

FIGURE 21 Helium Coolant System in PPPL Tokamak

Impurities enter this coolant loop from several sources: 1) water from the steam heat exchanger, 2) tritium diffused from the flibe, and 3) a small quantity of wall material activated by neutron sputtering. A side stream representing 13 percent of the entire coolant flow is purified in a cleanup system to keep impurity concentrations to low levels.

Description of Helium Cleanup System. Separate cleanup systems will be required for water and for hydrogenic species. A molecular sieve adsorbent bed was suggested for water removal, but no specific method was proposed for removal of hydrogen isotopes. The UWMAK-I system design was the basis for an assumed yttrium foil adsorber for hydrogen removal. The main helium flow passes through the yttrium beds to remove hydrogenic species (Figure 22). The $Y$ beds would be operated in pairs, with one unit adsorbing while the other was being stripped thermally. A third unit would serve as a backup and would be used when one of the units was out of service. Water is removed from a small sidestream by molecular sieve adsorbers operating on an adsorption-desorption cycle like the yttrium adsorbers. Desorbed water would be collected in a cold trap, and then electrolytically decomposed into $\mathrm{H}_{2}$ and $\mathrm{O}_{2}$. Most of the $\mathrm{O}_{2}$ would go to the gas separation system for final tritium removal. 


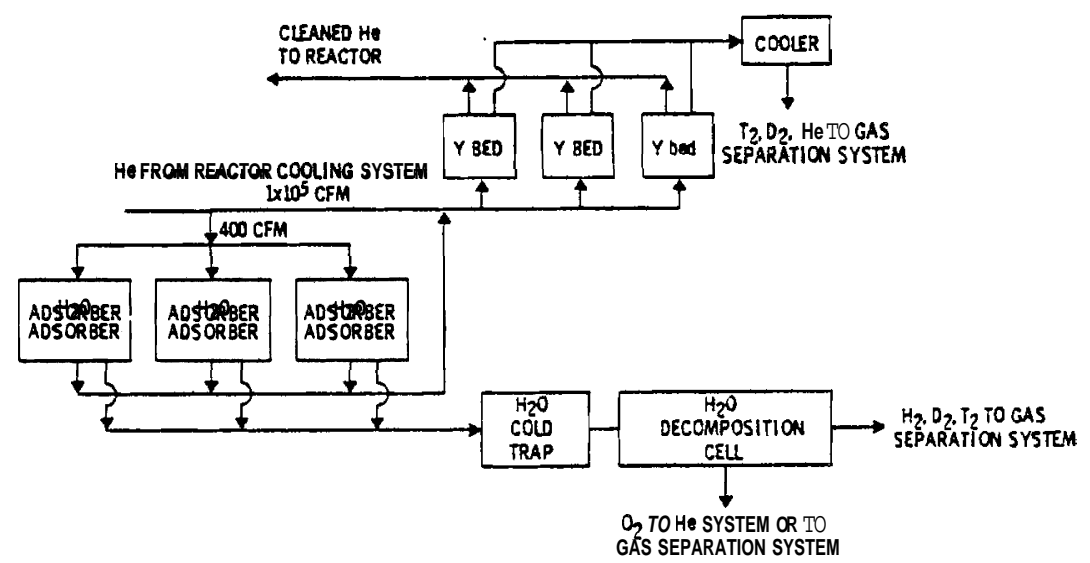

FIGURE 22 Helium Cleanup System for PPPL Tokamak

Treatment of Helium Cleanup System Waste. Wastes generated by the coolant cleanup processes are mainly spent adsorbents. A treatment system for these wastes is shown in Figure $\mathbf{2 3}$.

The quantity of spent yttrium was based on an assumed replacement of 2 beds per year. Scoping calculations indicated that each bed would contain $10 \mathrm{MI}$ of yttrium foil. If compacted to 50 percent of theoretical solid density, this yttrium foil would occupy a volume of $8 \mathrm{~m}^{\mathbf{3}}$. The activity (nontritium) on the spent uranium foil would result from deposition of neutron sputtered particles. It was assumed that 10 grams of helium borne particles would deposit per year, giving an activity of $40 \mathrm{Ci}$ of products with half-lives longer than 1 year.

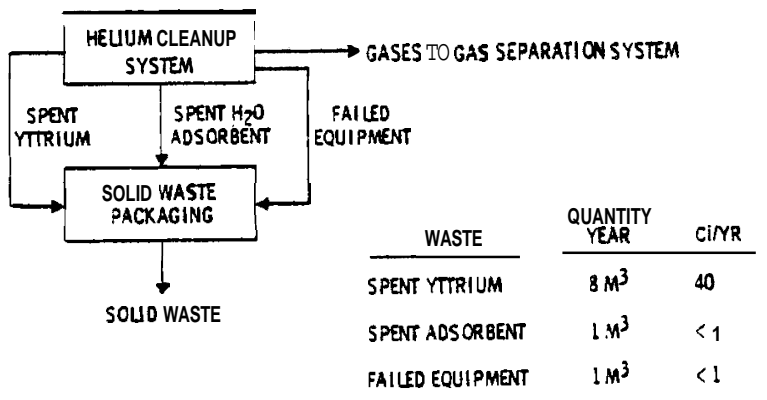

FIGURE 23 Treatment of Waste From Helium Cleanup System of PPPL Tokamak

Spent adsorbent volume discharged per year was estimated on the basis of an assumed replacement of material yearly. For the two units, scoping design calculations indicated that about $0.7 \mathrm{M}^{3}$ of material would be needed. Expected levels of radioactive materials would be low because the gas flow rate is so very low. On the basis of flow rate (as compared to the yttrium beds) only a fraction of a curie would be predicted.

Relatively little failure prone equipment is involved in the helium cleanup system, hence failed equipment would not represent a large volume. Also, residual activity levels would be low. Based on these expectations, the failed equipment volume was estimated to be less than $1 \mathrm{M}^{3}$, and the activity level less than $1 \mathrm{Ci}$. 


\subsubsection{PPPL Tokamak Facifity and Equipment Decontamination Processes}

Almost all of the equipment used in the primary circuits will be contaminated with neutron activation products and tritium. Removal of surface contamination will be required for contact repair and maintenance procedures.

Decontamination requirements and waste treatment in the PPPL plant are expected to be similar to those in the UWMAK-I. Results shown in Section 2.1.4 were modified to account for the higher specific activity of PE-16 $(4 \mathrm{Ci} / \mathrm{g})$. Estimated waste quantities and activity levels are summarized in Table 8.

TABLE 8 Waste From Decontamination Processes in PPPL Tokamak

\begin{tabular}{|c|c|c|}
\hline Nuclide & $\underline{C i / Y_{r}}$ & Half-Life \\
\hline${ }^{57} \mathrm{CO}$ & 320 & $271 d$ \\
\hline${ }^{60} \mathrm{Co}$ & 20 & $5.272 y$ \\
\hline${ }^{55} \mathrm{Fe}$ & 190 & $2.7 y$ \\
\hline${ }^{54} \mathrm{Mn}$ & 20 & $312.5 \mathrm{~d}$ \\
\hline${ }^{63} \mathrm{Ni}$ & 4 & $100 y$ \\
\hline $49 v$ & 2 & $331 d$ \\
\hline
\end{tabular}

The different material for the inner wall produces a different distribution of nuclides than the UWMAK-I. Concentration levels in cooling tower blowdown water were based on attaining 2 percent of the 10 CFR-20 limit for ${ }^{60}$ Co. The breakdown of activity for the important nuclides is shown in Table 9. Release of this quantity of radionuclides to the nearby water body would result in an excessive radiation dose (4000 man-rem/yr) in comparison to doses at current fission power plants. It is assumed that appropriate treatment facilities would be installed to reduce the dose.

$\underline{\text { TABLE } 9}$ Nuclide Activity in PPPL Tokamak

\begin{tabular}{|c|c|c|}
\hline Nuclide & $\mathrm{Ci} / \mathrm{Yr}_{\mathrm{r}}$ & Half-Life \\
\hline${ }^{57} \mathrm{Co}$ & 320 & $271 d$ \\
\hline${ }^{60} \mathrm{CO}$ & 20 & $5.272 y$ \\
\hline${ }^{55} \mathrm{Fe}$ & 190 & $2.7 y$ \\
\hline $54 \mathrm{Mn}$ & 20 & $312.5 d$ \\
\hline${ }^{63} \mathrm{Ni}$ & 4 & $100 y$ \\
\hline $40 v$ & 2 & $391 d$ \\
\hline TOTAL & 556 & \\
\hline
\end{tabular}

\subsubsection{PPPL Tokamak Equipment Replacement and Repair}

In addition to inner wall replacement and equipment replacements already considered, other equipment having low levels of contamination will be repaired and/or replaced. These items are neutral beam accelerators, fuel pellet formation equipment, and gas separation equipment. The PPPC equipment is similar to the equipment for UWMAK-l: hence the same estimate will be used. The estimated equipment volume is $30 \mathrm{~m}^{3} / \mathrm{Yr}$ and the estimated activity of this waste is 10 curies/year. 


\subsubsection{PPPL Tokamak Gas Separation System}

The gas separation system will be similar to that used in UMMAKI Therefore the waste discharged will be similar, and the quantities estimated for UMMKI appear to be applicable, These are summarized in Table 10.

$\underline{\text { TABLE } 10}$ Waste From Gas Separation System in PPPL Tokamak

\begin{tabular}{|c|c|c|}
\hline Waste & Quantity $/ \mathrm{Yr}_{r}$ & $\mathrm{Ci} / \mathrm{Yr}_{r}$ \\
\hline${ }^{41} \mathrm{Ar}$ & & 4000 \\
\hline $13 \mathrm{~N}$ & & 3400 \\
\hline${ }^{14} \mathrm{C}$ & & 30 \\
\hline Y & $100 \mathrm{~kg}$ & $<10$ \\
\hline Equi pment & $3 M^{3}$ & 1 \\
\hline
\end{tabular}

Argon is added to the plasma chamber to serve as a radiator. In UWMAKI argon reached the plasma only by leakage with air. De to the presence of the purposefuly added argon in PPPL, much higher inventories of ${ }^{41} \mathrm{Ar}$ will be present. However since argon will be recycled, the higher curie inventory will probably not lead to an appreciably higher curie discharge to the atmosphere. Based on the estimates made for UMMAKI the yearly discharge of gases is summarized in Table 11, assuming that ample holdup time is installed to eliminate almost all of the ${ }^{13} \mathrm{~N}$ and ${ }^{41} \mathrm{Ar}$.

TABLE 11 Gaseous Activation Products Released to Atmoshpere by PPPL

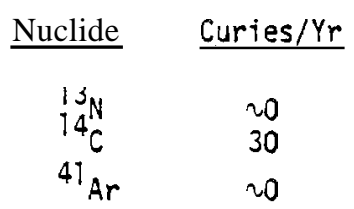

\subsection{WASTE TREATMENT SYSTEMS OF THE ORNL TOKAMAK}

\subsubsection{Lithium Cleanup System}

Blanket lithium circulates in the niobium inner wall to breed tritium and to remove heat. The lithium flow circuit is entirely within the reactor, and is pumped by magnetohydrodynamic pumps. Although the ORNL design document does not show a lithium cleanup system it was assumed to be required to remove corrosion products and impurities (Figure 24).

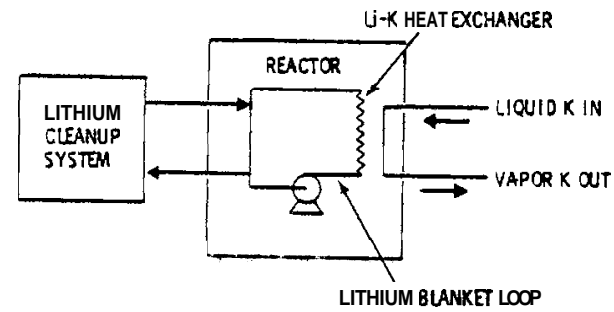

FGURE 24 Lithium Circuit in ORNL Tokamak 
Waste Treatment System For Lithium Cleanup. The lithium cleanup system is expected to be essentially the same as the system used to clean lithium in the UWMAK- plant. Waste quantities resulting from the lithium cleanup operation are surmarized in Table 12. The waste quantities and activities were projected on the same basis as for UWMAK-, accounting for a higher specific activity of the niobium wall in the ORN plant. For the niobium wall, a specific activity of $5 \mathrm{Ci} / \mathrm{g}$ is predicted compared to about $1 \mathrm{Ci} / \mathrm{g}$ for the $316 \mathrm{SS}$ used in UWMAK-I.

TABLE 12 Waste Quantities Resulting From Lithium Purification in ORN Tokamak

\begin{tabular}{lcl}
\multicolumn{1}{c}{ Waste } & Quantity/Year & $\mathrm{Ci} / \mathrm{Yr}$ \\
$\mathrm{Zr}$ Foil + & $80 \mathrm{Mr}$ & $2 \times 10^{7}$ \\
Corrosion Products & $80 \mathrm{~kg}$ & $5 \times 10^{4}$ \\
$\mathrm{Li}_{2} \mathrm{O}$ & $1 \mathrm{M}^{3}$ & 5 \\
Equi pment & &
\end{tabular}

\subsubsection{ORN Tokamak Potassium Cleanup System}

Liquid potassium is the vehicle for transporting heat from the blanket lithium to the steam generator. The potassium also removes tritium from the lithium so it can be recycled. The potassium loop is shown in Figure 25.

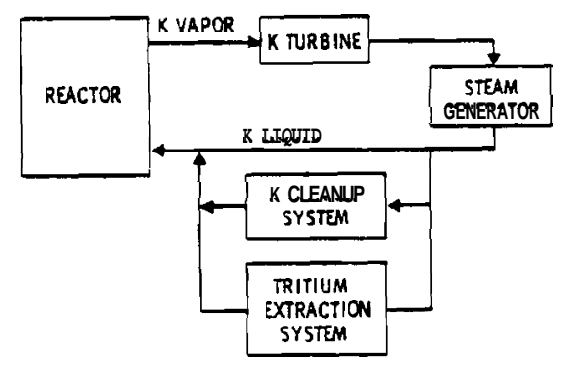

FIGURE 25 Potassium Loop in OPN Tokamak

Waste Treatment System For Potassium Cleanup System. The potassium system in the ORN plant is similar to the sodium loop in the UWMAK-I plant, and hence the cleanup system is expected to be similar to that sodium cleanup system. An additional system would be needed to remove tritium in the potassium loop. Waste quantities estimated to result from the potassium cleanup system are summarized in Table 13. The quantities of waste are identical to those estimated to result from the sodium purification system described in Section 2.1.2. Curie levels are 5 times higher than estimated for the UMMAK- sodium system, reflecting the higher specific activity of the niobium wall of the ORN design. 
$\underline{\text { TABLE } 13}$ Waste Quantities Resulting From Potassium Purification in ORNL Tokamak

\begin{tabular}{|c|c|c|}
\hline Waste & Quantity/Year & $\mathrm{Ci} / \mathrm{Yr}_{\mathrm{r}}$ \\
\hline Zr foil & $10 \mathrm{MT}$ & $5 \times 10^{2}$ \\
\hline $\mathrm{K}_{2} \mathrm{O}$ & $80 \mathrm{~kg}$ & 5 \\
\hline Equipment & $1 M^{3}$ & $<5$ \\
\hline
\end{tabular}

Waste Treatment System For Tritium Extraction System. Tho potential means for tritium extraction were noted in the ORNL design. The base system proposed involved extraction of tritium by mixing lithium with potassium to form lithium tritide, separation of the lithium, potassium, and lithium tritide, decomposition of the tritide, and collection of tritium through a tritium window. A backup method involved trapping of tritium on yttrium. Neither method was described with enough detail to allow waste to be identified. It may be assumed that the backup method employing yttrium would be similar to the processes described for UMMAKH On this basis waste quantities were estimated for a yttrium trap system that would be similar to that used to remove tritium from the diverter lithium system in UMMAKI Waste quantities and activity levels are summarized in Table 14. The estimated quantity of waste is identical to values estimated for the diverter lithium system used in UMMAKI Activity levels 5 times higher than estimated for UMMAK $¥$ were used here to account for the higher specific activity of the niobium wall material.

TABLE 14 Waste Quantities Resulting From Tritium Extraction in ORNL Tokamak

\begin{tabular}{|c|c|c|}
\hline Waste & Quantity/Year & $\mathrm{Ci} / \mathrm{Yr}_{\mathrm{r}}$ \\
\hline Spent Y & $1.4 \times 10^{3} \mathrm{~kg}$ & $5 \times 10^{3}$ \\
\hline Equipment & $1 \mathrm{M}^{3}$ & 5 \\
\hline
\end{tabular}

\subsubsection{ORNL Tokamak Vacuum System}

The vacuum system is used to pump down the plasma chamber between burns. A pumping speed of $5 \times 10^{4}$ liters per second was specified to achieve the required pumpdown in 20 seconds. Beyond this size specification, little detailed information was available. Therefore, it was assumed that the ORNL vacuum system would be the same as that used in the PPPL plant. On this basis, waste from the vacuum system would be the same for the PPPL plant as stated in Table 15.

Radioactivity levels are the same as those estimated for the PPPL plant. since the specific activity of the inner wall is about the same for the PPPL and ORNL plants, similar activity levels would be expected.

TABLE 15 Waste Resulting From Vacuum System in ORNL Plant

\begin{tabular}{lcc} 
& Quantity/Year & $\frac{C i / Y r}{1}$ \\
\cline { 2 - 3 } H Amalgam & $3 \mathrm{MT}$ & $7 \times 10^{6}$ \\
Solidified Oil & $2 \mathrm{M}^{5}$ & $<1$ \\
Equipment & $30 \mathrm{M}^{3}$ & 40
\end{tabular}




\subsubsection{ORNL Tokamak Shield Cooling System}

A magnet shield, consisting of lead and graphite enclosed in a titanium shell, is used to protect the magnets, and to capture tritium diffusing from the hot blanket structure. Helium at $10 \mathrm{~atm}$ pressure circulates through the shield to cool it. Few details of the shield coolant design are given, therefore, waste effluents were based on the helium cooling circuit used to cool the shield in UWMAKI Wastes from the helium cooling system described for UWMAK-I are summarized in Table 16. While the waste quantities are the same as those estimated for the UMMAK $\$$ plant, the curie levels are 5 times higher, at the time when the wastes are removed from the system, reflecting the higher specific activity of the niobium wall. However the relative short half-lives for the most important niobium isotopes should rapidly reduce the activity to insignificant levels. TABLE 16
Wastes Resulting From Shield Cooling System
in ORNL Plant

$\begin{array}{ccl}\text { Waste } & \text { Quantity/Year } & \text { Ci/Yr } \\ \text { Spent Yttrium } & 100 \mathrm{~kg} & <50 \\ \text { Equipment } & 1 \mathrm{M}^{3} & <5\end{array}$

\subsubsection{ORNL Tokamak Facility and Equipment Decontamination Processes}

Equipment in the primary circuits will be contaminated with neutron activation products and tritium. Removal of surface contamination will be required for contact repair and maintenance procedures.

Decontamination requirements and resulting waste treatment in the ORNL plant are expected to be similar to those postulated for the PPPL plant. Waste quantities and activity levels are summarized in Table 17.

TABLE 17 Wastes From Decontamination Processes in ORNL Plant

\begin{tabular}{|c|c|c|}
\hline Waste & Quanti ty/Year & Ci/Yr \\
\hline Organic Residues in Bitumen & $30 M^{3}$ & 160 \\
\hline Inorganic Residues in Concrete & $300 \mathrm{M}^{3}$ & 160 \\
\hline Laundry Water & 100,000 gal & 65 \\
\hline
\end{tabular}

The niobium wall used in the ORNL plant leads to different activation products in the ORNL plant effluents. Concentration levels in cooling tower blowdown water were based on the release limit for ${ }^{92 m_{N b}}$ as defined by 10 CFR-20. The breakdown of activity for nuclides with halflives longer than 10 hours are shown in Table 18. 
TABLE 18 Initial Distribution of Radionuclides from the Activation of Niobium $-1 \%$ Zirconium in ORNL Tokamak

\begin{tabular}{|c|c|c|}
\hline$\underline{\text { Nuclide }}$ & $\underline{\text { Half Life }}$ & $\underline{\text { Percent of Total }}$ \\
\hline${ }^{92} \mathrm{Nb}$ & $2 \times 10^{7} y$ & 0.005 \\
\hline $92 m_{\mathrm{Nb}}$ & $10.16 d$ & 92.0 \\
\hline $93 m_{N b}$ & $13.6 y$ & 0.15 \\
\hline $95 m_{N b}$ & $90 \mathrm{~h}$ & 3.1 \\
\hline${ }^{95}{ }_{\mathrm{Nb}}$ & $35 d$ & 3.1 \\
\hline${ }^{89} \mathrm{Zr}$ & $78.4 h$ & 0.05 \\
\hline${ }^{93} \mathrm{Zr}$ & $1.5 \times 10^{6} y$ & 0.003 \\
\hline${ }^{95} \mathrm{Zr}$ & $65.5 d$ & 0.001 \\
\hline $90_{Y}$ & $64 \mathrm{~h}$ & 0.15 \\
\hline $91_{Y}$ & $58.8 d$ & 0.0006 \\
\hline${ }^{89} \mathrm{Sr}$ & $52.7 d$ & 1.53 \\
\hline & Total & $100 \%$ \\
\hline
\end{tabular}

Because of the relatively short half-lives for most of these nuclides, installation of a tank to hold the laundry water for at least one year would result in decay of most of the activity to such a low level that less than one curie per year would be released.

\subsubsection{ORNL Tokamak Equipment Replacement and Repair}

In addition to replacement of the inner wall and equipment replacements already considered, other equi pment items repaired or replaced are neutral beam accelerators and fuel pellet making equipment. This equipment is similar to the equipment for UMMKK and PPPL plants. Based on the waste estimates for the PPPL plant, the estimated equipment volume is $30 \mathrm{~m}^{3} / \mathrm{yr}$ for the $0 \mathrm{RNL}$ Tokamak and the estimated activity of waste is 10 curjes/year.

\subsubsection{ORNL Tokamak Gas Separation System}

The gas separation system will be similar to that used in the UWMAK-I and PPPL plants. Little air inleakage is expected because the plasma chamber is wholly located inside a vacuum building evacuated to $10^{-3}$ torr. Solid waste from the gas separation system are expected to be the same as for the PPPC plant as in Table 19.

$\underline{\text { TABLE } 19}$ Wastes From Gas Separation in ORNL Plant

\begin{tabular}{|c|c|}
\hline Waste & Quantity/Year \\
\hline Spent Ytrrium & $100 \mathrm{~kg}$ \\
\hline Equi pment & $3 M^{3}$ \\
\hline
\end{tabular}




\subsection{THETA PINCH WASTE PROCESSING SYSTEMS}

\subsubsection{Lithium Processing System}

The blanket is cooled by liquid lithium metal that circulates between the blanket and external heat exchangers. An intermediate sodium loop transfers the heat to the steam generators. Impurities and tritium are removed from the lithium by processing systems.

To extract tritium sputtering and corrosion products, the lithium is to be contacted with a LiC1-KCl eutectic. This kind of system has not been demonstrated. It is proposed that the impurities other than tritium be removed by electrochemical deposition. The lithium processing system is shown in Figure 26.

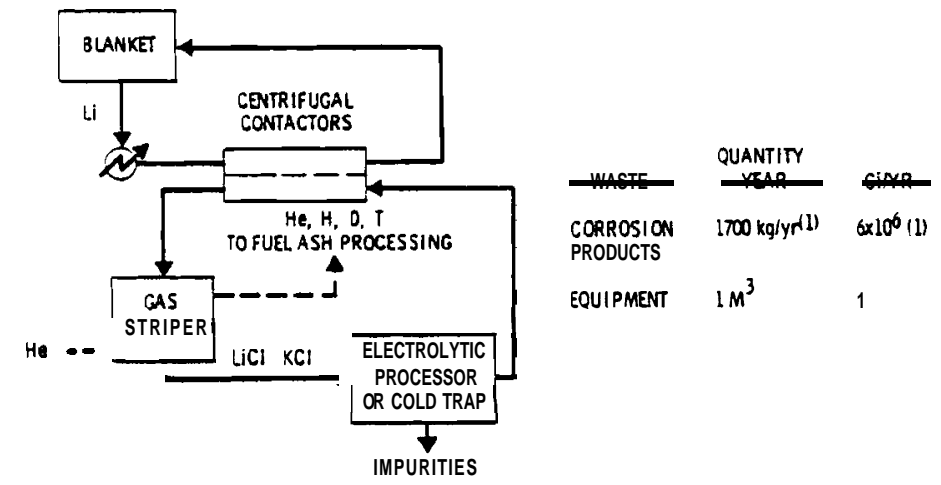

FIGURE 26 Lithium Processing System for Theta Pinch

The primary waste stream from the lithium processing system is the corrosion and sputtering products removed from the molten salt extractant by electrolytic and/or cold trapping. The corrosion and sputtering products are assumed to have the same composition and radioisotope distribution as the first wall. There may also be some $\mathrm{L}_{2} \mathrm{O}$ removed, however the amount of $\mathrm{Li}_{2} \mathrm{O}$ produced in the theta pinch should be much lower than in the tokamak designs because lithium is not exposed to the plasma chamber gases.

\subsubsection{Theta Pinch Fuel-Ash Processing System}

This system removes helium and other contaminants in the fuel-ash stream leaving the plasma chamber, and in the tritium-deuterium stream extracted from the lithium processing system. The system consists of cryogenic distillation towers with associated compressors and heat exchangers plus a catalyzer to improve the separation of hydrogen and deuterium. Small amounts of sputtering and corrosion products may be entrained in the incoming gas stream causing some contamination of the process equipment. However, the main radionuclide in the system will be tritium, so that any waste streams must be handled as tritium waste. The kind of waste stream resulting will be failed equipment. The volume of waste represented by failed equipment should be relatively small and is estimated to be no more than $1 \mathrm{~m}^{3} / \mathrm{yr}$. It was assumed that this failed equipment would be contaminated (nontritium) with about 1 gram of erosion products with an associated activity of 1 curie. The estimated waste from this system is summarized in Table 20. 
TABLE 20 Radwaste From the Fuel-Ash Processing System in Theta Pinch

$\frac{\text { Waste }}{\text { Failed Equipment }} \quad \frac{\text { Quantity/Year }}{1 \mathrm{M}^{3}} \quad \frac{\text { Curie/Year }}{1}$

\subsubsection{Theta Pinch Vacuum System}

The vacuum system for the theta pinch reference reactor has not been defined. It was assumed that the vacuum system will be similar to that proposed for the PPPL tokamak design and that the amount of vacuum system waste is proportional to the thermal power of the reactor. The estimated amounts of waste are given in Table 21.

TABLE 21 Estimated Amounts of Waste From the Vacuum System in Theta Pinch

\begin{tabular}{|c|c|c|}
\hline Waste & Volume/Year & Curie/Year \\
\hline Hg Sludge & $0.7 M^{3}$ & $1.6 \times 10^{7}$ \\
\hline Solidified Pump 0 il & $5 M^{3}$ & $<2$ \\
\hline Failed Equipment & $70 \mathrm{M}^{5}$ & 90 \\
\hline
\end{tabular}

\subsubsection{Theta Pinch Shield Cooling System}

The shield cooling system has not been designed therefore the system and wastes were assumed to be similar to those for the ORN tokamak. The quantity and activity of the wastes are also assumed to be proportional to the thermal power of the reactor so that the ORN tokamak estimates were multiplied by a factor of 12 to get the values listed in Table 22.

\begin{tabular}{|c|c|c|}
\hline Waste & Quantity/Year & Curie/Year \\
\hline Spent Yttrium & $1200 \mathrm{~kg}$ & $<600$ \\
\hline Equipment & $1 M^{3}$ & $<12$ \\
\hline
\end{tabular}

\subsubsection{Theta Pinch Facility and Equipment Decontamination Processes}

Wastes resulting from decontamination are assumed to be similar to the decontamination wastes from an ORN tokamak, but the activities of the dried waste residues, and the activity and quantity of laundry waste water are assumed to be proportional to the thermal power of the reactor. Waste quantities and activity levels are summarized in Table 23.

TABLE 23 Waste From Decontamination Processes in Theta Pinch

$\begin{array}{lccc}\text { Waste } & \text { Quantity/Year } & & \text { Curie/Year } \\ \text { Organic Residues in Bitumen } & 30 \mathrm{M}^{3} & & 380 \\ \text { Inorganic Residues in Concrete } & 300 \mathrm{M}^{3} & 380 \\ \text { Laundry Water } & 100,000 \mathrm{gal} & 160\end{array}$


The bulk of the radioactivity is assumed to be activation products of $\mathrm{Nb}-15 \mathrm{Zr}$ alloy. The distribution of these activation products with half-lives longer than 10 hours is given in Table 18. Storage for one year should reduce activity to an insignificant level.

\subsubsection{Theta Pinch Equipment Replacement and Repair}

The volume of failed equipment is assumed to be the same as for the OPN tokamak while the activity is assumed to be greater in proportion to the thermal power of the reactor. Based on these assumptions, the estimated equipment volume is $30 \mathrm{~m}^{3} /$ year for the theta pinch reactor and the estimated activity is 120 curies/year.

\subsection{WASTE TREATMENT SYSTEM FOR MINIMUM ACTIVATION BLANKET DESIGN}

This blanket is cooled by separate water and helium circuits. Both streams will be processed to remove radioactive aluminum activation products.

Corrosion and Sputtering Products in the Coolant. Based on light water reactor experience, corrosion of the aluminum alloy by the water coolant will contaminate the water with activated corrosion products. These corrosion products may be removed by evaporation or ion exchange from a side stream of coolant and incorporated in the concrete used to immobilize the corrosion products. If all the water can be assimilated by the concrete, no evaporation or ion exchange step will be necessary.

The helium coolant may contain some sputtered aluminum. It is not known whether the sputtering products will be transported from their point of origin, or if they are suspended in the helium, what physical form they might have or how they might best be removed from the helium coolant. The influence on radwaste volumes of removing corrosion products from the coolant should be very small. The additional radioactivity in the radwaste from this source is estimated to be about 10 curies per year.

Vacuum Pump Waste. The main source of activation product bearing waste may arise from the trapping of sputtering products in the vacuum pumping system. The sputtering products will probably be adsorbed by the cryopump adsorbent, amalgamate with the diffusion pump mercury, and also contaminate pumping equipment and pump oil.

A maximum of $2.5 \%$ of the aluminum dished heads of the blanket modules is expected to be sputtered away during the three year Iife of the module (Powe11, et al., 1974).

This amounts to about $1600 \mathrm{~kg} / \mathrm{yr}$ of sputtering products trapped by the vacuum system. The total amounts of vacuum system waste is extrapolated from UMMAK- waste quantities by assuming that the quantity of mercury and charcoal in the waste is proportional to the amount of sputtering products (Table 24 ).

TABLE 24 Vacuum System Waste From the Minimum Activation Blanket Reactor

\begin{tabular}{|c|c|c|}
\hline Waste & Quantity/Year & $\begin{array}{l}\text { Curies/Year } \\
\text { (1 yr aging) }\end{array}$ \\
\hline $\mathrm{Hg}+$ Sputtering Products Sludge & $1.6 \mathrm{MT} / \mathrm{yr}$ & 6 \\
\hline Charcoal and $0 \mathrm{il}$ & $40 \mathrm{MT} / \mathrm{yr}$ & 6 \\
\hline Failed Equipment & $30 \mathrm{~m}^{3} / \mathrm{yr}$ & $10^{-4}$ \\
\hline
\end{tabular}


The distribution of radionucl ides in these wastes is given in Table 25 .

TABLE 25 Nuclide Activity in Minimum Activation Blanket Reactor

$\begin{array}{cc}\text { Isotope } & \begin{array}{c}\text { Percent } \\ \text { Total Curies } \\ (1 \text { year decay })\end{array} \\ { }^{54} \mathrm{Mn} & 37 \\ 110_{\mathrm{Sn}} & 23 \\ { }^{55_{\mathrm{Fe}}} & 20 \\ { }^{64} \mathrm{Zn} & 10 \\ { }^{58} \mathrm{Co} & 3 \\ { }^{96} \mathrm{Zr} & 2 \\ 26_{\mathrm{Al}} & 5\end{array}$

Decontamination Waste and Laundry Water. The volumes of solidified decontamination waste and laundry water are assumed to be the same as for UWMAK-I but the radioactivities due to activated structural elements will be only about $1 \%$ of the corresponding radioactivities estimated for UWMAK-I. The distribution of radioisotopes in this waste should be approximately the same as in the vacuum system waste given in Table 24.

With appropriate storage and treatment of the laundry water, the number of curies released should result in an insignificant radiation dose to the general public. 


\subsection{SUMARY OF RADIOACTIVE WASTE VOLUMES}

This section summarizes the estimated amounts of waste resulting from normal fusion reactor operation as discussed in the previous sections. In addition, the number of 55 gallon drums of solid waste was estimated, allowing for void spaces, inert binders and shielding.

\subsection{UWMAK-I}

The sources and quantities of solid and gaseous waste produced by operation of a UWMAK-I reactor are summarized in Table 26, 27 and 28.

TABLE 26 Summary of Solid Waste From UWMAK-I

\begin{tabular}{|c|c|c|c|c|}
\hline Waste Description & Source & Quantity/Year & Curtes/Year & №. of 55 gal. Orums \\
\hline Zirconium Foil & Impurity Traps & $1.1 \times 10^{5} \mathrm{~kg} / \mathrm{yr}$ & $5 \times 10^{6}$ & 80 \\
\hline $\mathrm{Li}_{2} \mathrm{O}$ & Li Cold Traps & $880 \mathrm{~kg} / \mathrm{yr}$ & $1.1 \times 10^{5}$ & 2 \\
\hline Yttrium Foil & T Gettering & $1870 \mathrm{~kg} / \mathrm{yr}$ & 1100 & 2 \\
\hline $\mathrm{Na}_{2} \mathrm{O}$ & Na Cold Traps & $80 \mathrm{~kg} / \mathrm{yr}$ & 1 & (combine with $\mathrm{LI}_{2} \mathrm{O}^{\text {) }}$ \\
\hline Charcoal & Cryopumps & $4 \times 10^{4} \mathrm{~kg} / \mathrm{yr}$ & $5 \times 10^{5}$ & 110 \\
\hline Equipment & Various & $70 \mathrm{~m}^{3} / \mathrm{yr}$ & 27 & 340 \\
\hline Concrete and $\mathbf{B i t u m e n}$ & Liquid Uaste Immobilization & $330 \mathrm{~m}^{3} / \mathrm{yr}$ & $80 \mathrm{ct} / \mathrm{yr}$ & 1580 \\
\hline Other Solids ' & Hg Purification & $1.6 \times 10^{3} \mathrm{~kg}$ & $5 \times 10^{5}$ & $\underline{2}$ \\
\hline & & & Total & 2116 \\
\hline
\end{tabular}

TABLE 27 Surmary of Liquid Waste From UWMAK-1

$\begin{array}{lllll}\text { Disposition } & \begin{array}{c}\text { Waste } \\ \text { Description }\end{array} & \text { Source } & \text { Quantity/Year } & \text { Curios/Yoar } \\ \begin{array}{llll}\text { Released to } \\ \text { Environment }\end{array} & \text { Laundry } & \begin{array}{l}\text { Clothing } \\ \text { Waste Water }\end{array} & 100,000 \mathrm{ga} / / \mathrm{yr} & <1\end{array}$

$\underline{\text { TABLE } 28}$ Gaseous Waste Produced by UWMAK-I

\begin{tabular}{|c|c|c|}
\hline Descrip & Source & Curies/Year \\
\hline${ }^{41} \mathrm{Ar}$ & Activation of leaked air & $\sim 0$ \\
\hline $133_{N}$ & Activation of leaked air & w \\
\hline${ }^{14} \mathrm{C}\left(\mathrm{CO}_{2}\right)$ & Activation of leaked air & 30 \\
\hline
\end{tabular}




\subsection{PPPL TOKAMAK}

The sources and quantities of solid, liquid and gaseous waste produced by operation of a PPPL reactor are sumnarized in Table 29,30 and 31.

$\underline{\text { TABLE } 29}$ Sumnary of Solid Waste From PPPL Tokamak

\begin{tabular}{|c|c|c|c|c|}
\hline Waste Description & Source & $\begin{array}{c}\text { Quantity } \\
\text { Year }\end{array}$ & $\begin{array}{c}\text { Curies } \\
\text { Year }\end{array}$ & $\begin{array}{c}\text { Number of } \\
55 \text { gal. Drums }\end{array}$ \\
\hline Flibe + Corrosion Products & Salt Cleanup System & $33 M^{3}$ & $3.6 \times 10^{7}$ & 145 \\
\hline Contaminated KF Salt & TF Decomposition & $1 \mathrm{M}$ & 4 & 13 \\
\hline Hg Amalgam & Vacuum System & $2 M^{3}$ & $7 \times 10^{6}$ & 3 \\
\hline Solidified Oil & Vacuum System & $2 M^{3}$ & $<1$ & 10 \\
\hline Yttrium & $\mathrm{H}$ and Gas Sepin & $8 m^{3}$ & 40 & 38 \\
\hline Bitumen & Decon. Processes & $30 \mathrm{M}^{3}$ & 160 & 145 \\
\hline Concrete & Decon. Processes & $300 m^{3}$ & 160 & 1440 \\
\hline Equipment & Various & $66 M^{3}$ & 62 & 317 \\
\hline & & & Total & 2111 \\
\hline
\end{tabular}

TABLE 30 Summary of Liquid Waste Frbm PPPL Tokamak

$\frac{\text { Waste Description }}{\text { Laundry Waste Water }} \quad \frac{\text { Source }}{\text { Clothing Laundry }} \quad \frac{\text { Quantity/Year }}{100,000 \mathrm{gal}} \quad \frac{\text { Curies/Year }}{<1}$

This dilute aqueous waste would be released to the environment by mixing it with cooling tower blowdown water.

TABLE 31 Nontritium Gaseous Waste Released From PPPL Tokamak

\begin{tabular}{|c|c|c|}
\hline Waste Description & Source & Curies/Year \\
\hline${ }^{41} \mathrm{Ar}$ & Activation of leaked air & 20 \\
\hline $13 \mathrm{~N}$ & Activation of leaked air & no \\
\hline${ }^{14} \mathrm{C}\left(\mathrm{CO}_{2}\right)$ & Activation of leaked air & 30 \\
\hline
\end{tabular}

\subsection{ORNL TOKAMAK}

The sources and quantities of solid and liquid waste produced by operation of a ORNL reactor are surmarized in Table 32 and 33. N appreciable source of gaseous waste other than tritium has been identified in the ORNL plant. Air inleakage, the gaseous waste source in the UMMAKI and PPPL plants, is expected to be negligible because the reactor is located within a vacuum building. 
TABLE 32 Summary of Solid Waste From ORNL Tokamak

\begin{tabular}{|c|c|c|c|c|}
\hline Waste Description & Source & $\begin{array}{c}\text { Quantity } \\
\text { (Year) } \\
\end{array}$ & $\begin{array}{l}\text { Curies } \\
\text { (Year) }\end{array}$ & 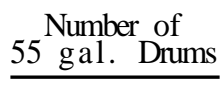 \\
\hline Zr Foil + Corrosion Products & $\mathrm{Li}$ and $\mathrm{K}$ Cleanup Systems & $90 \mathrm{MT}$ & $2 \times 10^{7}$ & 200 \\
\hline $\mathrm{Li}_{2} \mathrm{O}+\mathrm{K}_{2} \mathrm{O}$ & $\mathrm{Li}$ and K Cleanup Systems & $160 \mathrm{~kg}$ & $5 \times 10^{4}$ & 1 \\
\hline Spent Yttrium & Tritium Extraction & $1.6 \mathrm{~kg}$ & $5 \times 10^{3}$ & $<1$ \\
\hline Hg Amal gam & Vacuum System & $3 \mathrm{M}$ & $7 \times 10^{6}$ & 3 \\
\hline Solidified Oil & Vacuum System & $2 M^{3}$ & $<1$ & 10 \\
\hline Bitumen & Decon. Processes & $30 \mathrm{~m}^{3}$ & 160 & 144 \\
\hline Concrete & Cecon. Processes & $300 \mathrm{M}^{3}$ & 160 & 1441 \\
\hline \multirow[t]{2}{*}{ Equipment } & Various & $67 M^{3}$ & 71 & 322 \\
\hline & & & Total & 2121 \\
\hline
\end{tabular}

$\underline{\text { TABLE } 33}$ Sumary of Liquid Waste From ORNL Tokamak

$\frac{\text { Waste Description }}{\text { Laundry Waste Water }} \quad \frac{\text { Source }}{\text { Clothing Laundry }} \quad \frac{\text { Quantity/Year }}{100,000 \mathrm{gal}} \quad \frac{\text { Curies/Year }}{<1}$

\subsection{THETA PINCH}

A surmary of waste from the reference Theta Pinch reactor is given in Table 34.

$\underline{\text { TABLE } 34}$ Surmary of Waste From the Reference Theta Pinch Reactor

\begin{tabular}{l} 
Waste Description \\
\hline Lithiu and Corrosion Products \\
Failed Equipment \\
Falled Equipment \\
Mercury Sludge \\
Solidified Pump of1 \\
Failed Equipment \\
Spent Yttrium \\
Failed Equipment \\
Organic Residues in Bftumen \\
Inoqanlc Residues in Concrete \\
Laundry Water
\end{tabular}

Mise. Falled Equipment

Source
Lithium System
Lithium System
Fuel-ash System
Vacuum System
Vacuum System
Vacuum System
Shield Cooling System
Shield Cooling System
Decontamination
Decontamination
Laundering Protective Llothing
Varied

\begin{tabular}{|c|c|c|}
\hline Quantfty/Year & Curtes/Year & $\begin{array}{c}\text { Nunber of } \\
55 \text { gal. Orums }\end{array}$ \\
\hline $1700 \mathrm{~kg}$ & $6 \times 10^{6}$ & 12 \\
\hline $1 m^{3}$ & 1 & 5 \\
\hline $1 \mathrm{M}^{3}$ & 1 & 5 \\
\hline $0.7 M^{3}$ & $1.6 \times 10^{7}$ & 3 \\
\hline $5 M^{3}$ & $<2$ & 25 \\
\hline $70 m^{3}$ & 90 & 24 \\
\hline $1200 \mathrm{~kg}$ & 600 & 25 \\
\hline $1 M^{3}$ & 12 & 5 \\
\hline $30 \mathrm{~m}^{3}$ & 380 & 144 \\
\hline $300 m^{3}$ & 380 & 1441 \\
\hline 100,000 gai. & $<1$ & \\
\hline $30 \mathrm{M}^{3}$ & 120 & 144 \\
\hline & Total & 1833 \\
\hline
\end{tabular}

\subsection{MNMUM ACIIVATION BLANKET}

A summary of waste from the Minimum Activation Blanket design is given in Table 35. 
TABLE 35 Summary of Waste From Minimum Activation Blanket Design

\begin{tabular}{|c|c|c|c|c|}
\hline Waste Oescrfotion & Source & Quantity/Year & Curtes/Year & $\begin{array}{c}\text { Number of } \\
55 \mathrm{gal} \text {. Orums }\end{array}$ \\
\hline Mercury Sludge & Vacuura System & $1.6 \mathrm{~m}^{3}$ & 6 & 8 \\
\hline Charcoal and Solidified of & Vacuum System & $40 m^{3}$ & 6 & 192 \\
\hline Failed Equipment & Vacuum System & $30 M^{3}$ & $10^{-4}$ & 144 \\
\hline Organic Residues in Bitumen & Decontamination & $30 M^{3}$ & 0.4 & 144 \\
\hline Inorganic residues In Concrete & Decontamination & $300 M^{3}$ & 10 & 1441 \\
\hline Laundry Water & Laundering Protective Clothing & 100,000 gal. & $<$ & - \\
\hline & & & Total & 1929 \\
\hline
\end{tabular}




\subsection{POTENTIAL STUDY AREAS}

In preparing this review of radioactive waste treatment for fusion power reactors it has become apparent that many assumptions were required to determine the sources and disposition of wastes. Most of the uncertainties derive from the sketchy design of the plant systems, rather than unique problems associated with the waste disposal. This is expected because the conceptual designs focus primarily on the plasma physics problems rather than on the auxiliary systems.

The quantities and activity levels of some waste depends on the specific design of the fusion power plant. For example, large quantities of zirconium foil waste appears in the plant designs showing $\mathrm{Zr}$ getter beds used to remove corrosion products from lithium metal coolant. If other techniques for cleaning the coolant are used, this waste source could disappear. As another example, if a carbon liner were used to protect the inner metal wall, the level of neutron activation products might be appreciably reduced, but there could be an offsetting production of ${ }^{14} \mathrm{C}$.

Several aspects of waste treatment which represent fairly typical problems that wit require additional resolution have been identified and are briefly noted.

Disposal of Corrosion Products. Reactors which use cooling fluid other than helium will generate corrosion products that will be largely removed in cold traps. Additional studies are needed to determine whether to dispose of this material as is, or to convert it to a more inert form such as glass. A glass formulation would be relatively easy to develop for metal oxides, but a glass formulation would be a problem if corrosion products were present as fluorides (as in the PPPL flibe coolant).

Recycling of Yttrium and Zirconium. Yttrium is comparatively expensive $(\$ 500.00 / \mathrm{kg})$ and reprocessing might be chosen rather than storage as a radioactive waste. Additional studies would be worthwhile to determine the cost-benefit for recycling this material. Similar effort might be considered for less costly zirconium.

Reclaiming Contaminated Mercury. Reclaiming contaminated mercury by distillation is a common procedure today. Additional study would be worthwhile to determine what waste would result from cleanup where alkali metals are present in the mercury, and what should be the final form for this waste.

Solidification of Detergent Wastes. A major source of radioactive nuclides released to the environment is the laundry effluent water. While the activity levels are very low, they could be greatly reduced if a method were developed to solidify detergent waste. The spent detergent and contaminants could then be retained and stored as solids rather than being discharged to the environment as a liquid waste. This problem is not unique to fusion reactors but also exists for present fission reactors.

Disposition of Contaminated Vacuum Pump Oil. It was assumed that contaminated pump oil derived from the vacuum pumps would be mixed with a solid sorbent on immobilization. Such a process needs more study to show that the mixture can be considered a solid, and to show the degree to which tritium is immobilized by such a procedure. 
Transport and Deposition of Wall Erosion Material. Due to neutron and photon bombardment, erosion of the inner wall is expected. The eroded wall material is assumed to enter the plasma as an ionic species that is removed along with other plasma particles by the vacuum and diverter systems. Additional study should be directed at determining to what extent these erosion products cool, condense, or plate out in the various chambers and flow passages. Knowledge of transport characteristics would aid in determining activity levels in waste originating from the vacuum system and the diverter circuit.

Activation of Inleaked Air. It was assumed that air would leak into the vacuum plasma chamber at a rate of $0.1 \%$ per day based on the volume of the plasma chamber. This leak rate was taken from experience in low leakage containment vessels used to house fission reactors. This quantity of inleaked air results in a modest source term for gaseous radioactive waste because of neutron activation of nitrogen and argon. Additional study to more thoroughly evaluate the rate of air leakage would show whether this source term has been realistically assessed, particularly for designs with secondary vacuum chambers. 


\subsection{INNER WAL DISPOSAL EFFECTS}

The replacement of fusion reactor structures damaged by neutron irradiation is expected to be an important source of radioactive waste arising from fusion power plant operation. Fortunately most of the radioactivity is bound up in the structure as activation products which minimizes the likelihood of release. On the other hand, many of the activation products are isotopes of the structural material elements so that separation or removal of the radioactivity is impractical, making prompt reuse of highly activated materials difficult, if not impossible.

One scheme that now appears to be feasible for managing this waste would include the following steps: 1) removal of unbound tritium, 2) removal of smearable activated material from the structure surfaces, 3) size reduction (to reduce packaging, shipping and storage costs), 4) packaging, and 5) shipping and storage. The decision whether to store the waste at the reactor site or to ship the waste to a central repository would depend both on safety and economic considerations which, in turn, depend on the radioisotopes involved.

While there may be some improvement possible in the waste management scheme described here, the greatest opportunities for minimizing the radioactive waste problem appear to lie in reducing the production of long lived radionuclides through careful selection of materials of construction and in the design of the reactor. Certainly the management cost and hazard of the radioactive waste should be considered in optimizing fusion reactor designs.

\subsection{QUANTITY AND COMPOSITION OF ACTIVATED STRUCTURE}

The amount of activated waste material projected for the various hypothetical fusion reactor design is estimated from the size of the structures and their expected service lifetimes.

Table 36 summarizes these estimates as compiled from various fusion reactor design documents. The information in this table provides the main basis for this study of the inner wall disposal problem. This table shows how the amount of solid radwaste and the distribution of radionuclides strongly depends on the wall material selected.

\subsection{REQUIRED STORAGE TIME FOR ACTIVATED MATERIALS}

The activated wall material must be stored in some controlled manner until the radioactivity decays to a level which permits unrestricted use, or else to a level where the material may be economically reused. To estimate the limits of the storage time, the time was calculated for the radioactivity to decay to concentrations in the metal equal to the maximum permissible concentration in air as defined in $10 \mathrm{CR} 20$. The results for proposed inner wall materials are summarized in Table 37. These times represent the outer limits for required safe storage time. In some cases the material may be safely and economically reclaimed and reused for a nuclear application long before the radioactivity has reached (MPC) levels. Nevertheless these limiting storage times provide one measure of the relative radioactive waste management problem associated with the various materials of construction.

Of the materials shown in Table 37, the vanadium-titanium alloy has the shortest storage time and therefore appears to be the'most recyclable material. The short storage time required should result in a relatively inexpensive storage facility at the reactor site. The vanadiumtitanium alloy must not contain impurities producing appreciable amounts of long-lived and hazardous activation products. Therefore, the purity requirements may make this alloy relatively expensive. 
TABLE 36 Summary of Projected Radwaste Generation From Various Conceptual Fusion Designs (Tritium excluded)

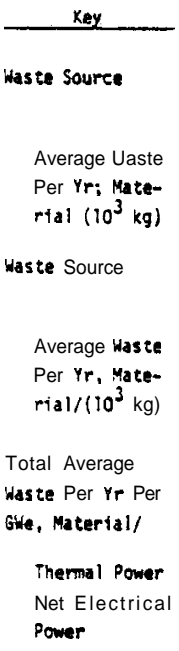

Activity/Afterhedt O Annual Waste Quantity: (MCI)/ (m):

At Shutdown

After Brief

Decay

After 1 Yr

After NYrs;

$N:(M C !) /($ MN)

Major sourtes of

Long-Lived

Radioactivity:

Material

[sotopes/

$T 1 / 2(Y \mathbf{r})$

Ummak.I
Bianket: finner
$20 \mathrm{~cm}(2 \mathrm{yr}$ life)
$55 / 250$
Blanket: outer
$53 \mathrm{~cm}(10 \mathrm{yr}$ Iife)
$55 / 520$

S\$/543, Cort./1.8

BN Blanket
Blanket; full
depth (3 yr life)
Al/230, C/180,
A1 ${ }_{2} \mathrm{O}_{3} / 43$,
LiA $10_{2} / 4$
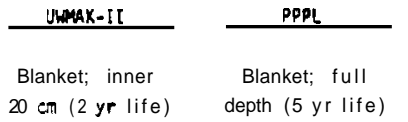

$\frac{\text { ORML }}{\text { Blanket; full }}$

Blanket: full $20 \mathrm{~cm}$ (2 yr life)

Pe-16/220

$\mathrm{Nb} / 14, \mathrm{C} / 110$

LIA10 $2 / 220$.

$$
\text { Be/ } 215
$$

Blanket; outer 69 on (10 yr life)

$0 / 43$

$A 1 / 150, C / 118$
$A 1,0,27$
$\mathrm{LA}_{2} \mathrm{3}_{2} / 2.4$
5.0
1.6

$\$ \$ / 167$ LiA $10, / 129$, Be/ $126, C / 25$

4.7

1.5

5.0
1.7

Similar to UWMAK-I

7001

$350 / 1$

$20: \quad 5 / 0.01$

10: $0.0003 /$

SS structure

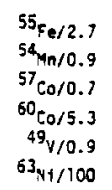

Structural impurtities \& Al

$54_{Y n / 0.9}$

$119 \mathrm{~m}_{\mathrm{S} n / 0.7}$

$55_{\mathrm{Fe} / 2.7}$

$65 \mathrm{Zn} / 0.7$

$26+1 / 7 \times 10^{5}$
40001

$700 / 2.5$

200017

$300 / 0.6$

20: 101

P3-16

structure

${ }^{57}$ Co/ 0.7

$55_{\mathrm{Fe} / 2.7}$

${ }^{60} \mathrm{Co} / 5.3$

$54_{\text {M } / 0.9}$

$4991 / 100$

Ni 100
$49 / 0.9$ depen (5 ye life)

$\mathrm{Nb} / 77 \mathrm{O}, \mathrm{C} / 140$, $\mathrm{Be} / 10$
/ / $188, C / 34$.

$80 / 2.4$

12.0

4.1

$\begin{array}{ll}1.0 & 12.0 \\ 0.5 & 4.1\end{array}$


TABLE 37 Maximum Storage Time for Wall Materials

\begin{tabular}{|c|c|c|c|c|}
\hline Material & $\begin{array}{l}\text { Maximum } \\
\text { Storage } \\
\text { Time }\left(Y_{r}\right) \\
\end{array}$ & $\begin{array}{c}\text { Limiting } \\
\text { Radionuclide } \\
\end{array}$ & $\begin{array}{c}M P C \\
\mu \mathrm{C} i / \mathrm{m} \mathbf{1}\end{array}$ & $\mathrm{t} 1 / 2, \mathrm{Yr}$ \\
\hline $\mathrm{V}-20 \mathrm{TH}$ & 23 & ${ }^{45} \mathrm{Ca}$ & $9.6 \times 10^{-10}$ & 0.45 \\
\hline $316 \mathrm{SS}$ & 3300 & $63_{\mathrm{Ni}}$ & $1.9 \times 10^{-9}$ & 92 \\
\hline$N b-1 \% 2 r$ & $10^{7}-10^{8}$ & $\begin{array}{l}93 \mathrm{Zr} \\
92_{\mathrm{Nb}}\end{array}$ & $\begin{array}{l}4 \times 10^{-9} \\
1 \times 10^{-10}\end{array}$ & $\begin{array}{c}10^{7} \\
1.5 \times 10^{6}\end{array}$ \\
\hline PE 16 & $10^{5} \mathrm{Yr}$ & $93_{\text {Mo }}$ & $2.5 \times 10^{-8}$ & $210^{4} \mathrm{Yr}$ \\
\hline$A l-M g-S i$ & $10^{7} \mathrm{Yr}$ & ${ }^{26} \mathrm{Al}$ & $3 \times 10^{-8}$ & $7.3 \times 10^{5}$ \\
\hline
\end{tabular}

The niobium-zirconium alloy requires very long storage times reminiscent of fission reactor waste. The long $\left(10^{5} \mathrm{yr}\right)$ storage time for PE-16 is due to activation of molybdenum which is a minor constituent of the alloy. If the molybdenum were absent the storage time for PE-16 would be about 4000 years which is comparable to the storage time for 316 stainless steel.

Tables 38, 39, 40 and 41 give a detailed breakdown of decay times for the individual activation products formed in four of these alloys. The high levels of activation mean that an uncertainty in the initial activity has a minor effect on the time estimate for decay to MPC levels. This means that activation product inventories calculated by different investigators are comparable in spite of variation in operation time, neutron fluence, and cross sections.

$\underline{\text { TABLE } 38}$ Time Required for Activation Products in V-20 Ti to Decay to MPC Levels

\begin{tabular}{|c|c|c|c|c|}
\hline Isotope & $\begin{array}{l}\text { Initial } \\
\text { Activity } \\
\text { Ci/ce } \\
\end{array}$ & $\begin{array}{c}\mathrm{MPC} \\
\mathrm{Ci} / \mathrm{CC}\end{array}$ & $\mathrm{t}] / 2$ & $\begin{array}{l}\text { Decay Time } \\
\text { to MPC, Y } \\
\end{array}$ \\
\hline${ }^{45} \mathrm{Ca}$ & 1.14 & $9.6 \times 10^{-16}$ & $165 d$ & 22.6 \\
\hline${ }^{46} S C$ & 0.945 & $8 \times 10^{-16}$ & $83.9 d$ & 11.5 \\
\hline${ }^{47}$ SC & 0.7 & $2 \times 10^{-14}$ & $3.43 d$ & 0.4 \\
\hline${ }^{48}$ SC & 5.38 & $4.9 \times 10^{-5}$ & $1.83 d$ & -- \\
\hline${ }^{49} \mathrm{Sc}$ & 0.172 & $3 \times 10^{-14}$ & $57.5 \mathrm{~m}$ & $\cdots$ \\
\hline${ }^{50}{ }_{S C}$ & 0.252 & $3 \times 10^{-14}$ & $1.72 \mathrm{~m}$ & -- \\
\hline${ }^{45_{T i}}$ & 0.051 & $1 \times 10^{-16}$ & $3.09 \mathrm{~h}$ & -- \\
\hline${ }^{51} \mathrm{Ti}$ & 7.03 & $3 \times 10^{-13}$ & $5.79 m$ & -- \\
\hline $52 \mathrm{v}$ & 9.16 & $2.3 \times 10^{-13}$ & $3.75 \mathrm{~m}$ & -- \\
\hline
\end{tabular}


TABLE 39 Time Required for Longer Lived Activation Products in 316 SS to Decay to MPC Levels

\begin{tabular}{|c|c|c|c|c|}
\hline Isotope & $\begin{array}{l}\text { Initial } \\
\text { Activity } \\
\text { Ci/ce } \\
\end{array}$ & $\begin{array}{c}M P C \\
\mathrm{Ci} / \mathrm{CC}\end{array}$ & $\pm 1 / 2$ & $\begin{array}{l}\text { Decay Time } \\
\text { to MPC, Yr } \\
\end{array}$ \\
\hline $49 v$ & $3 \times 10^{-5}$ & $1 \times 10^{96}$ & $333 d$ & 34.4 \\
\hline${ }^{51} \mathrm{Cr}$ & 11.3 & $8 \times 10^{-14}$ & $27.8 d$ & 3.57 \\
\hline${ }^{54} \mathrm{Mn}$ & 10.8 & $1 \times 10^{-15}$ & $303 d$ & 44.2 \\
\hline${ }^{55} \mathrm{Fe}$ & 62.2 & $3 \times 10^{-14}$ & $2.6 y$ & 132 \\
\hline${ }^{59} \mathrm{Fe}$ & $2.2 \times 10^{-2}$ & $2 \times 10^{-15}$ & $45.6 d$ & 5.4 \\
\hline${ }^{57} \mathrm{Co}$ & 4.59 & $5.9 \times 10^{-15}$ & $270 d$ & 36.5 \\
\hline${ }^{58} \mathrm{Co}$ & 12.7 & $2 \times 10^{-15}$ & $71.3 d$ & 10.2 \\
\hline${ }^{60} \mathrm{Co}_{\mathrm{O}}$ & 2.08 & $3 \times 10^{-16}$ & $5.26 y$ & 277 \\
\hline${ }^{63} \mathrm{Ni}$ & $1.3 \times 10^{-4}$ & $1.9 \times 19^{-15}$ & $92 y$ & $3300 y$ \\
\hline
\end{tabular}

$\overline{\text { From Badger et a }}$ i, 1974

TABLE 40 Time Required for Longer Lived Activation Products in NB-7\% Zr to Decay to NPC Levels

\begin{tabular}{|c|c|c|c|c|}
\hline Isotope & $\begin{array}{l}\text { Initial } \\
\text { Activity } \\
\text { Ci/cc } \\
\end{array}$ & $\begin{array}{c}\mathrm{MPC} \\
\mathrm{Ci} / \mathrm{CC} \\
\end{array}$ & $+1 / 2$ & $\begin{array}{l}\text { Decay Time } \\
\text { to NPC, Y } r\end{array}$ \\
\hline $92_{\mathrm{Nb}}$ & $3.5 \times 10^{-2}$ & $1 \times 10^{-16}$ & $22 \times 10^{7} y$ & $210^{8}$ \\
\hline $92 m_{N b}$ & 684 & $1 \times 10^{-16}$ & $10.16 \mathrm{~d}$ & 1.74 \\
\hline $93 m_{N b}$ & 1.35 & $1 \times 10^{-15}$ & $13.6 y$ & 656 \\
\hline $95 m_{\mathrm{Nb}}$ & 8.46 & $1 \times 10^{-16}$ & $90 \mathrm{~h}$ & 4.7 \\
\hline${ }^{95} \mathrm{Nb}$ & 1.84 & $3.1 \times 10^{-15}$ & $35 \mathrm{~d}$ & 4.7 \\
\hline${ }^{89} \mathrm{Zr}$ & 0.45 & $1 \times 10^{-16}$ & $78.4 \mathrm{~h}$ & 0.5 \\
\hline${ }^{93} \mathrm{Zr}$ & $2.67 \times 10^{-3}$ & $4 \times 10^{-15}$ & $i .5 \times 10^{6} y$ & $5.9 \times 10^{7}$ \\
\hline $91_{Y}$ & $5.11 \times 10^{-3}$ & $1 \times 10^{-19}$ & $58.8 d$ & 8.9 \\
\hline${ }^{89} \mathrm{Sr}$ & 16.8 & $3 \times 10^{-16}$ & $52.7 d$ & 10 \\
\hline
\end{tabular}

From Badger et a 1,1974 
TABLE 41 Time Required for Longer Lived Activation

Products in Al-Mg-Si to Decay to MPC Levels

\begin{tabular}{|c|c|c|c|c|}
\hline [sotope & $\begin{array}{c}\text { Initial } \\
\text { Activity } \\
\text { Ci/cc(a) } \\
\end{array}$ & $\begin{array}{c}\mathrm{MPC} \\
\mathrm{Ci} / \mathrm{CC}\end{array}$ & t $1 / 2$ & $\begin{array}{l}\text { Decay Time } \\
\text { to MPC, Yr }\end{array}$ \\
\hline $4_{M n}$ & $5.8 \times 10^{-6}$ & $1 \times 10^{-15}$ & $303 \mathrm{~d}$ & 27 \\
\hline${ }^{119} 9_{\mathrm{Sn}}$ & $3.9 \times 10^{-6}$ & $4 \times 10^{-10}$ & $245 d$ & 8.9 \\
\hline${ }^{55} \mathrm{Fe}$ & $2.7 \times 10^{-6}$ & $3 \times 10^{-14}$ & $2.6 y$ & 69 \\
\hline${ }^{58} \mathrm{Co}$ & $1.4 \times 10^{-6}$ & $2 \times 10^{-15}$ & $71.3 d$ & 5.7 \\
\hline${ }^{95} \mathrm{Zr}$ & $7.6 \times 10^{-7}$ & $1 \times 10^{-15}$ & $65.5 d$ & 5.3 \\
\hline${ }^{26} \mathrm{Al}$ & $6.4 \times 10^{-7}$ & $3 \times 10^{-14^{(b)}}$ & $7.3 \times 10^{5} y$ & $1.8 \times 10^{7}$ \\
\hline
\end{tabular}

(a) Calculated from J. R Powell, "Preliminary Reference Design of a Fusion Reactor Blanket Exhibiting Very Low Residual Radioactivity - Draft" Table 6.4, December 1, 1974; assuming activity evenly distributed in $1.5 \times 106 \mathrm{lb}$ of Aluminum Alloy.

(b) Estimate

\subsection{TREATMENT OF INNER WALL PRIOR TO STORAGE}

The spent blanket materials generally will have to be processed before storage or disposal.

The final waste package must be of manageable size, the activity must be nondispersible, and an economic recovery of usable blanket materials should be made. In order to accomplish these things the blanket processing scheme might be as depicted in Figure 27.

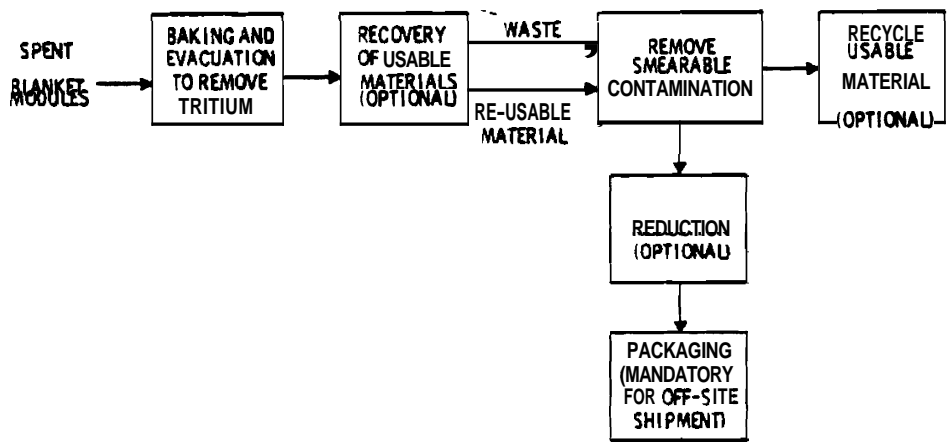

FIGURE 27 Blanket Processing for Storage or Disposal

The decontamination steps shown will probably be necessary in any case to minimize the hazard from tritium and finely divided or soluble activation products. Deciding to recover usable blanket materials imnediately depends on the value of the materials involved and waste storage cost saved versus the increased cost of recovering highly activated materials.

The size reduction step is intended to save money by reducing the amount of storage volume and packaging. The cost of size reduction should then be low enough to realize a net savings. 
Packaging may not be necessary if the smearable contamination can be removed and the materials can be reasonably handled without packaging. For shipment of the waste offsite, packaging will be mandatory. Size reduction may also be required so that the waste materials will fit into acceptable containers.

Tritium Removal. Tritium absorbed or dissolved in the blanket materials would be a hazard if it desorbed or outgassed during waste processing and storage.. To avoid this problem it has been proposed by Powell and coworkers (1974) that the blanket modules be heated in a high vacuum to a suitable temperature which may be 600 to $800^{\circ} \mathrm{F}\left(300\right.$ to $400^{\circ} \mathrm{C}$ ). The outgassed tritium would be trapped in titanium beds for recovery. The optimum temperature for outgassing the tritium would depend on the blanket material. Without specific information about the solubility of tritium in the blanket materials, it would seem reasonable to outgas at temperatures exceeding the maximum temperature expected during subsequent waste storage. This outgassing would be a batchwise operation with evacuation time on the order of one day. For blankets containing lithium and flibe, some of the lithium or flibe will melt and drain away from the blanket structure at high temperatures.

Removal of Smearable and Soluble Materials with Decontaminating Solutions. There are two approaches possible for managing the spent inner wall and blanket structures after removing the uncombined tritium: 1) to place the structures within high integrity containers which provide the primary protection against dispersal, and 2) to first remove all smearable and soluble material such as corrosion products, flibe and lithium from the structures before packaging blanket material. However, complete removal of lithium or flibe from the blanket structure may require other systems. Dissolving these substances in water would be the most obvious method of removal. When lithium is dissolved in water, decomposition of LiT would result in the evolution of $\mathrm{HT}$ gas which probably would have to be trapped, oxidized and fixed. Some of the tritium would also combine with the water solvent perhaps making the water too radioactive to release. Water that is already contaminated with tritium from other plant operations could be used as the solvent to avoid creating additional tritiated waste.

Size Reduction. The reason for size or volume reduction is to save cost of packaging and shipping. Therefore the cost of size reduction and compaction should be balanced against the savings in anticipated shipping, storage costs and reclaimed material. Because of the radiation hazard, the size reduction operation would have to be carried out remotely in a shielded cell. Any size reduction would probably involve cutting metal. Available metal cutting techniques that might be applicable are: cutting torches, saws or abrasive wheels, shears and, in some special instances, shaped explosive charges. Compaction could be carried out by hydraulic presses or melting. Melting would probably be quite expensive because of the high meiting point of most of the metals proposed for the blanket structures. However, melting may advantageously fix smearable radioactivity.

Packaging. The primary purpose for packaging contaminated equipment is to prevent dispersal of radioactivity during handling and shipping to a final storage site. If offsite shipping is not required, elaborate packaging may not be necessary. At ERDA's Hanford plant, contaminated equipment is packaged in wooden or concrete boxes for local storage or disposal (Committee, 1969). Wooden boxes, lined with plastic are inexpensive and suitable far nonretrievable disposal or for retrievable storage under conditions where the wood and plastic would not decompose. Concrete boxes will not rot and cost less than metal containers. The concrete 
containers are especially suited for retrievable burial because of their high strength under compressive loads, but they are heavy which is a disadvantage if the waste must be shipped a long distance. The kind of packaging chosen then depends on the specific disposal method.

\subsection{STORAGE OF ACTIVATED INNER WALL STRUCTURES}

The choice of storage method will depend on 1) where the material is to be stored, 2) whether the material is to be retrieved, and 3) the length of time the material remains hazardous.

The decision to store onsite or at a federal repository should logically account for the relative hazards and costs of either alternative. Even though the waste is shipped offsite, some onsite storage will be necessary while scheduling shipments or to allow time for reducing the radiation level and heat generation rate before shipping.

For retrievable storage of large, heavy contaminated items, the shielded tunnel used at Hanford (WASH-1538) should be suitable. As shown in Figure 28, the tunnel is made of reinforced concrete and is lined with galvanized steel. The tunnel is covered with soil for shielding. Large pieces of contaminated equipment are packaged and placed on railroad flat cars which can be remotely moved into the tunnel. The tunnel may be filled with soil after it is no longer used. A tunnel with openings at both ends should be useful when temporary storage is required to provide decay or cooling time. The oldest material can be removed at the outlet without excessive handling or reshuffling. Radiogenic heat may be removed by ventilating the tunnel.

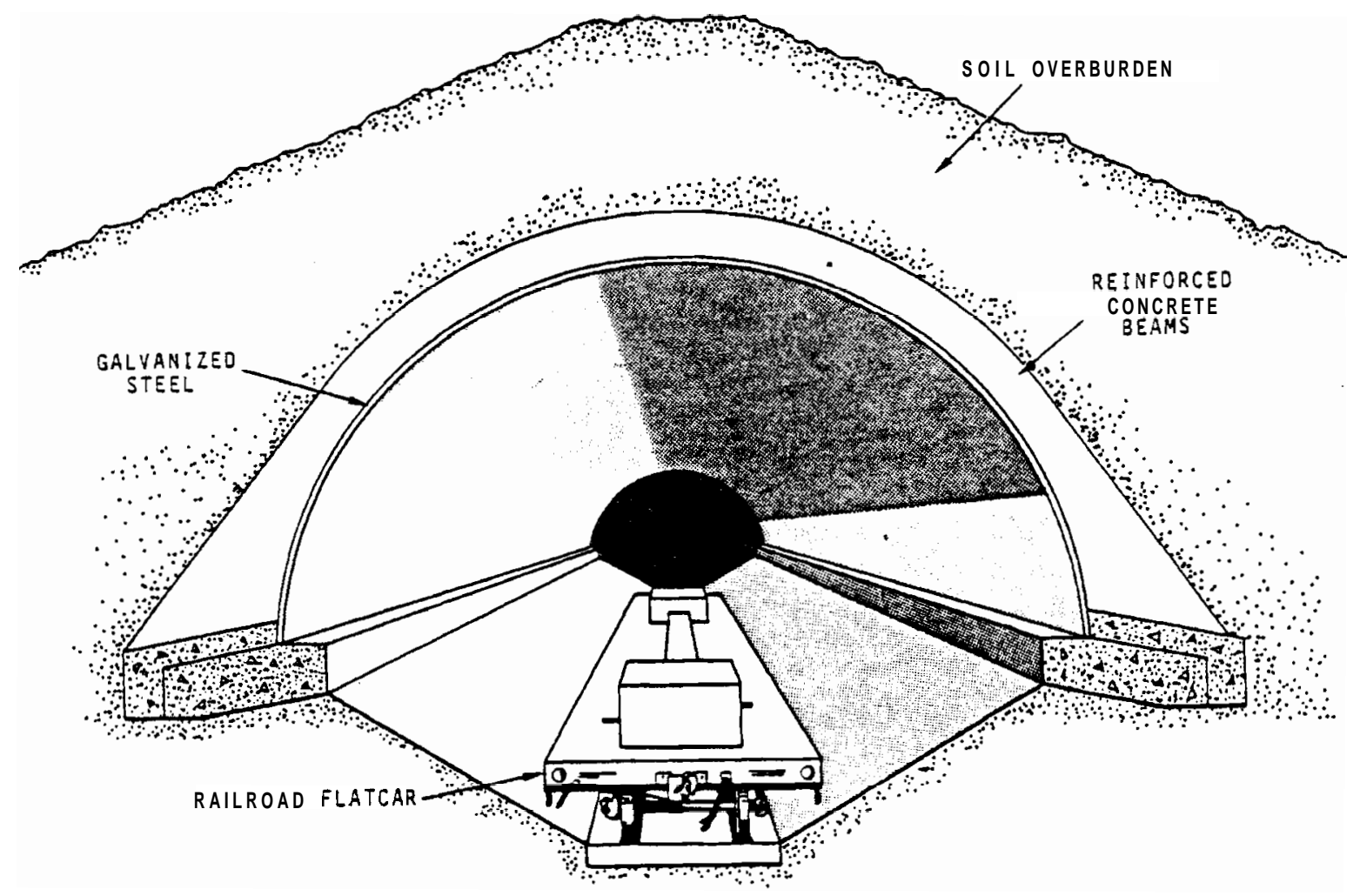

FIGURE 28 Tunnel for Storage of Radioactive Equipment 
In the storage of cylindrical blanket modules, Powell and coworkers (1974, pp 96-100) have suggested dropping the modules into cased holes in the ground. The casing would be closed at the bottom, water tight and anchored so that it cannot float upward due to ground water pressure. Figure 29 shows a typical storage well. There are many other methods available for onsite storage ranging from simple burial trenches useful for long-term nonretrievable storage, to water basins suited for temporary storage of blanket structures with very high radiogenic heating rates.

Some of the concepts for the design of federal repositories that have been described recently (WASH-1297) for the disposal of high-level radioactive waste resulting from the reprocessing of fission reactor fuels should generally be suitable for offsite storage of activated inner wall structures.

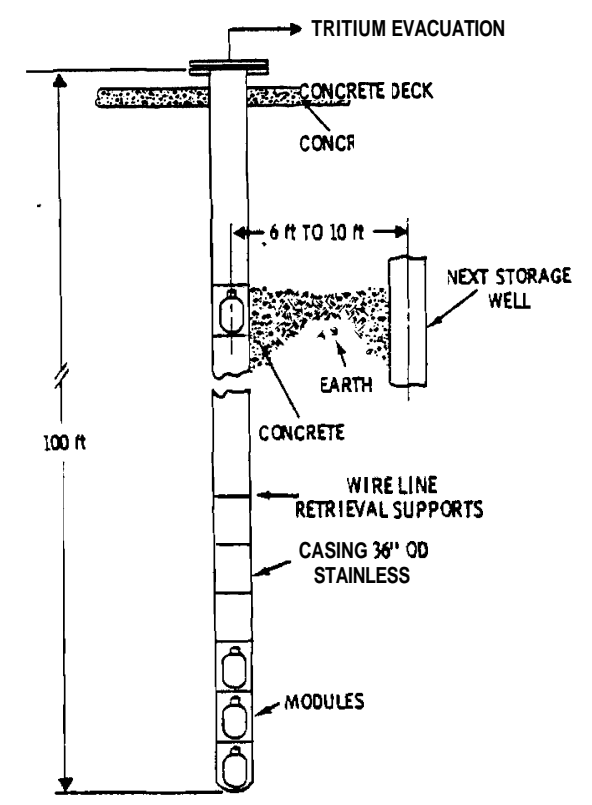

FIGURE 29 Typical Module Storage Well (25 Modules per Well)

A retrievable surface storage concept should be particularly useful for spent inner walls because the recovery value of this waste is high and the hazard is low compared to fission reactor waste. Some of the possible onsite storage schemes such as tunnels and wells described previously can be used for retrievable surface storage at a federal repository.

Storage in cavities mined in geologic formations should reduce the likelihood of release of radioactivity. However, the size of waste packages would be limited by the size of the mined cavity which in turn depends on the depth of the cavity and the structural strength of the formation. Another disadvantage is that retrieval may be more difficult and expensive. Sea bed disposal may be used but would probably make retrieval still more uncertain and expensive compared to storage in a geologic formation. 


\subsection{RADIOACTIVE EFFLUENTS FROM PROCESSING SPENT INNER WALL STRUCTURES}

A result of processing the inner wall structures for storage will be radioactive wastes such as spent decontamination solutions, floor drain liquids, ventilation filters, and cold traps. The contribution of the radioactivity in these wastes to the total amount of radioactive effluents resulting from routine reactor operation should be negligible because: 1) It has been assumed that the coolant purification systems are effective. (As a result, the inventory of mobile activation products remaining in the coolant is much smaller than the amount removed per year by the purification systems.) 2) The processing of the inner wall structure essentially removes only the mobile or smearable activation products from these structures. 3) The lifetime of the inner wall is greater than one year, so that a relatively small amount of waste would be generated relative to the waste generated directly by reactor operations. From these assumptions it follows that, except for the inner walls themselves, the radioactive effluents resulting from processing the inner wall for disposal will contain much less radioactivity than the active effluents resulting from routine reactor operation. The radioactive waste side streams from inner wall disposal can be combined and treated with the radioactive waste from reactor operation without any appreciably increased environmental consequences. 


\section{REFERENCES}

Badger, B. and Coworkers, UWMAK-I, A Wisconsin Toroidal Fusion Reactor Design, UWFDM-68, University of Wisconsin, Revised March 1974.

Committee on Radioactive Waste Management of the National Academy of Sciences, Presentations to, Management of Radioactive Wastes at the Hanford Plant, Richland, Washington, June 23 and $24,1969$.

Coultas, T. A and Coworkers, An Enqineering Design of a Reference Theta-Pinch (RTPR), ANL-8019, January 1974.

Fraas, A. P., Conceptual Design of the Blanket and Shield Region and Related Systems for a Full Scale Toroidal Fusion Reactor, ORN TM-3096, May 1973.

Mills, R. G., Ed., A Fusion Power Plant, MATT-1050, Princeton Plasma Physics Laboratory, 1974.

Powell, J. R and Coworkers, Preliminary Reference Design of a Fusion Reactor Blanket Exhibiting Very Low Residual Radioactivity, unnumbered draft report, December 1974.

WASH-1 297, USAEC Report, High Level Radioactive Waste Managment Alternatives, May 1974.

WASH-1538, ERDA Report, Draft Environmental Statement - Waste Management Operations - Hanford Reservation, Richland, Washington, July 1974. 
OFSITE

A. A. Churm

QDA Chicago Patent

Group

9800 S. Cass Avenue

Argonne, IL 60439

J. W. Beal

QDA Div. of Magnetic

Fusion Energy

Washington, DC 20545

S. 0. Dean

ADA Div. of Magnetic Fusion Energy

Washington, DC 20545

E. E. Kintner

ADA Div. of Magnetic

Fusion Energy

Washington, OC 20545

J. M. Williams

ADA Div. of Magnetic

Fusion Energy

Washington, DC 20545

J. N. Grace

ADA Div. of Magnetic Fusion Energy

Washington, DC 20545

J. Baublitz

AOA Div. of Magnetic

Fusion Energy

Washington, DC 20545

3 F. E. Coffman

BDA Div. of Magnetic

Fusion Energy

Washington, OC 20545

J. F. Decker

PRA Div. of Magnetic

Fusion Energy

Washington, DC 20545

3 K. M. Zwilsky

ADA Div. of Magnetic

Fusion Energy

Washington, DC 20545

Dr. Philip M. Stone

QDA Applied Plasma Physics

Program

Washington, DC 20545

G. W. Kuswa

PDA Div. of Laser Fusion

Washington, OC 20545
R. Blaunstein

ADA Div. of Biomedical and Environmental Research

Washington, $\mathbb{C} 20545$

H. M. Busey

ADA Div. of Military

Application

Washington, DC 20545

M. A Bell

IRA Div. of Safety

Standards and Compliance

Washington, DC 20545

27 PDA Technical Information Center

M. S. Kaminsky

Argonne National Laboratory

9700 S. Cass Avenue

Argonne, IL 60439

V. A Maroni

Argonne National Laboratory

9700 S. Cass Avenue

Argonne, IL 60439

P. M. Persiani

Argonne National Laboratory

9700 S. Cass Avenue

Argonne, IL 60439

M. Petrick

Engineering and Technology

Division

Argonne National Laboratory

9700 S. Cass Avenue

Argonne, IL 60439

W. E. Parkins, Manager

Atomics International

Component Engineering and

Technology Division

North American Rockwell

P.O. Box 309

Canoga Park, CA 91304

D. Gurinsky

Brookhaven National Laboratory

QDA Brookhaven Area Office

Upton, NY 11973

H. J. Kouts

Brookhaven National Laboratory

QOA Brookhaven Area Office

Upton, NY 11973

S. Pearlstein

Brookhaven National Laboratory

QRDA Brookhaven Area Office

Upton, NY 11973
OFFSITE

J. R. Powell

Brookhaven National Laboratory ADA Brookhaven Area Office Upton, NY 11973

A. J. Impink, Jr.

Carnegie Mellon University

Pittsburgh, PA 15213

R. A. Gross

Plasma Research Laboratory

236 SW Mudd Bldg.

Columbia University

New York, NY 10027

W. C. Gough

Electric Power Research Inst.

3412 Hillview Ave.

Palo Aito, CA 94304

G. R. Hopkins

Gulf General Atomic

P.O. Box 1111

San Diego, CA 92112

Zeinab Sabri

lowa State University

261 Sweeney Hall

Nuclear Engineering Department

Ames, IA 50010

R. Borg

Lawrence Livermore Laboratory

P.O. Box 808

Livermore, CA 94550

T. K. Fowler

Lawrence Livermore Laboratory

P.O. Box 808

Livermore, CA 94550

R. Moir

Lawrence Livermore Laboratory

P.O. Box 808

Livermore, CA 94550

A Carl Haussmann

Lawrence Livermore Laboratory

P.O. Box 808

Livermore, CA 94550

J. Hovingh

Lawrence Livermore Laboratory

P.O. Box 808

Livermore, CA 94550

R. F. Post

Lawrence Livermore Laboratory

P.O. Box 808

Livermore, CA 94550

C. 3. Taylor

Lawrence Livermore Laboratory

P.O. Box 808

Livermore, OA 94550 
R. Werner

Lawrence Livermore

Laboratory

P.O. Box 808

Livermore, CA 94550

L. L. Wood

Lawrence Livermore

Laboratory

P.O. Box 808

Livermore, CA 94550

W. Bauer

Division Supervisor

of Physical Research

Sandia Labs Livermore

Livermore, CA 94550

L. Booth

Los Alamos Scientific

Laboratory

CTN Research

P.O. Box 1663

Los Alamos, M 87544

D. J. Dudziak

Los Alamos Scientific

Laboratory

CTN Research

P.O. Box 1663

Los Alamos, M 87544

D. B. Henderson

Los Alamos Scientific

Laboratory

CTN Research

P.O. Box 1663

Los Alamos, M 87544

E. L. Kemp

Los Alamos Scientific

Laboratory

CTN Research

P.O. Box 1663

Los Alamos, M 87544

F. L. Ribe

Los Alamos Scientific

Laboratory

CTN Research

P.O. Box 1663

Los Alamos, M 87544

L. Stewart

Los Alamos Scientific

Laboratory

CTN Research

P.O. Box 1663

Los Alamos, M 87544

K. Thomassen

Los Alamos Scientific

Laboratory

CTN Research

P.O. Box 1663

Los Alamos, M 87544 o. K. Harling

Massachusetts Institute of

Technology

Cambridge, MA 02139

Bruno Coppi

Department of Physics

Massachusetts Institute of

Technology

Cambridge, MA 02139

\section{Lidsky}

Dept. of Nuclear Engineering

Massachusetts Institute of

Technology

Cambridge, MA 02139

Norm Rasmussen

Dept. of Nuclear Engineering

Massachusetts Institute of

Technology

Cambridge, NA 02139

David Rose

Massachusetts Institute of

Technology

Cambridge, MA 02139

R. E. Stickney

Mechanical Engineering

Massachusetts Institute of

Technology

Cambridge, MA 02139

J. J. Reinrnann

NASA - Lewis Research Center

2100 Bookpark Rd.

Cleveland, 어 44135

Vincent Arp

National Bureau of Standards

Cryogenics Division

Boulder, Co 80302

J. F. Clarke

Oak Ridge National

Laboratory

P.O. Box Y

Oak Ridge, TN 37830

A. P. Fraas

Oak Ridge National

Laboratory

P.O. Box Y

Oak Ridge, TN 37830

J. Rand MeNally, Jr.

Oak Ridge National

Laboratory

P.O. Box Y

Oak Ridge, TN 37830

D. Steiner

Oak Ridge National

Laboratory

P.O. Box Y

Oak Ridge, TN 37830
OFFSITE

J. Scott

Oak Ridge National Laboratory

P. 0. Box X

Oak Ridge, TN 37830

J. Banford

Physics International

2700 Merced St.

San Leandro, CA 94577

R. A. Huse

Public Service Electric and Gas Co.

80 Park Place

Newark, NJ 07101

$M$ Gottlieb

Princeton University, PPPL

P.O. Box 451

Princeton, NJ 08540

R. G. Mills

Princeton University

P.O. Box 451

Princeton, NJ 08540

E. C. Tanner

Princeton University

P.O. Box 451

Princeton, NJ 08540

H. Perkins

Dept. of Chemistry

Princeton University

Princeton, NJ 06540

R. E. Gold

303 Sayre Hall

Forrestal Campus

P.O. Box 451

Princeton, NJ 06540

M Kristiansen

Texas Tech. University

Lubbock, TX 79409

A. F. Haught

United Aircraft Research Lab.

United Aircraft Corporation

East Hartford, CT 06108

L. Levine

U.S. Naval Research Laboratory

Washington, \& 20390

C. Z. Serpan, Jr.

U.S. Naval Research Laboratory

Washington, DC 20390

Francis Chen

University of California

Electronics Research

Laboratory

College of Engineering

Berkeley, CA 94720 
No. of

$\underline{\text { Copies }}$

K. Sherman

Washington State Energy Office

1000 Cherry

Olympia, WA 98504

M. Walsh

Department of Ecology

State of Washington

Olympia, WA 98504

A. J. Eliopulos

Public Service Commission

Supreme Court Building

Cheyenne, WY 82002

D. 8. Freudenthal

State Planning Coordinator's Office

Office of the Governor

State Capitol

Cheyenne, WY 82002

D. Hoffman

Mineral Development Division

Department of Economic Planning and Development

720 West 18th Street

Cheyenne, WY 82002

F. C. Blood

Bonneville Power Administration

P.O. Box 3621

Portland, OR 97208

R. S. Gens

Bonneville Power Administration

P.O. Box 3621

Portland, OR 97208

J. Hoozen

Bonneville Power Administration

P.O. Box 3621

Portland, OR 97208

J. C. Loosli

Bonneville Power Administration

P.O. Box 3621

Portland, OR 97208

C. M. Moore

Bonneville Power Administration

P.O. Box 3621

Portland, OR 97208

M. Katz

Northwest Energy Policy Project 1096 Lloyd Building

700 N.E. Multnomah Street

Portland, OR 97232

R. Lewis

Northwest Energy Policy Project

1096 Lloyd Building

700 N.E. Multnomah Street

Portland, OR 97232
No. of

Copies

W. E. Bruner

Pacific Northwest Regional Commission

1205 Washington

Vancouver, WA 98660

D. J. Lane

Pacific Northwest River Basins Commission

1 Columbia River

P.O. Box 908

Vancouver, 98660

Dr. 0. Osborne

Oregon State University

Electrical Engineering

Department

Corvallis, OR 97331

Dr. R. Wensink

Oregon State University

Agricultural Engineering

Department

Corvallis, OR 97331

Dr. J. Jaksch

Corvallis Environmental Research Laboratory

Corvallis Environmental Protection Agency

Corvallis, R 97331

ง. Brar

Washington State University

Pullman, 99163

G. Hinman

Washington State University

Pullman, 99163

R. T. Miller

Vice President

Engineering and Gas Control

Northwest Natural Gas Company

123 N.W. Flanders Street

Portland, OR 97209

H. S. Johnson

Portland General Electric Co. 621 S.W. Alder Street

Portland, OR 97205

G. A. Perrault

Portland General Electric Co.

621 S.W. Alder Street

Portland, OR 97205

C. L Sauvie

Portland General Electric Co.

621 SW. Alder Street

Portland, OR 97205
No. of

Copies

J. L. Williams

Portland-General Electric Co. 621 S.W. Alder Street

Portland, OR 97205

R. A. Duncan

Coordination Engineer

Northwest Power Pool

920 S.W. 6th Ave., Rm. 1210

Portland, OR 97204

H. Kosmata

Washington Public Power Supply System

3000 George Washington Way

Richland, 99352

D. Renberger

Washington Public Power Supply System

3000 George Washington Way

Richland, 99352

R. Tillson

Washington Public Power Supply System

3000 George Washington Way

Richland, 99352

R. Woodruff

Washington Public Power Supply System

3000 George Washington Way

Richland, 99352

D. N. Morris

The Rand Corporation

1700 Main Street

Santa Monica, CA 90406

J. W. Ellis

Puget Sound Power and Light Company

Puget Power Building

Bellevue, 98009

L. E. Hall

Puget Sound Power and Light Company

Puget Power Building

Bellevue, 98009

B. C. Thomas

Puget Sound Power and Light Company

Puget Power Building

Bellevue, 98009

T. E. Browne

Electric Power Research Institute

$3412 \mathrm{Hi} l$ lview Avenue

P.O. Box 10412

Palo Alto, CA 94304 
S. H. Smiley

NRC Directorate of

Licensing for Fuels and

Materials

4915 St. Elmo Avenue

Bethesda, MD 20014

R B. Chitwood

Chief, Technical Support

Branch for Fuels and

Materials

4915 St. Elmo Avenue

Bethesda, MD 20014

W. P. Bishop

Chief, Waste Management Branch

NAC Division of Materials and Fuel Cycle Facility Licensing

Washington, D 20555

J. S. Parry

NCC Division of Materials and Fuel Cycle Facility Licensing

Washington, DC 20555

W. G Belter

ADA Division of Biomedical and Environmental Research

Earth Sciences Branch

Washington, D 20545

W. E. Mott

ERDA Division of Environmental Control Technology

Washington, D 20545

F. P. Baranowski

GDA Division of Nuclear Fuel

Cycle and Production

Washington, \& 20545

G. H. Daly

ERDA Division of Nuclear Fuel Cycle and Production

Washington, D 20545

W. K. Eister

ADA Division of Nuclear Fuel Cycle and Production

Washington, X 20545

O. P. Gormley

GDA Division of Nuclear Fuel Cycle and Production

Washington, $\mathbb{C} 20545$
C. R Cooley

ADA Division of Nuclear Fuel

Cycle and Production

Washington, $\mathbb{C} 20545$

A. F. Perge

ADA Division of Nuclear Fuel

Cvcle and Production

Washington, DC 20545

R. W. Ramsey

GDA Division of Nuclear Fuel Cycle and Production

Washington, C 20545

R. D. Walton

EDA Division of Nuclear Fuel Cycle and Production

Washington, DC 20545

C. W. Kuhlman

EDA Division of Nuclear Fuel Cycle and Production

Washington, DC 20545

D. W. Readey

GDA Division of

Physical Research

Washington, DC 20545

K. K. Kennedy

EDA Idaho Operations Office

P.O. Box 2108

Idaho Falls, ID 83401

E. H. Hardison

PDA Oak Ridge Operations Office

P.O. Box X

Oak Ridge, TN 37830

R. L. Chandler

GDA Savannah River Operations Office

P.O. Box A

Aiken, SC 29801

\section{J. A. Buckham}

Allied Chemical Corporation 550 - 2nd Street

Idaho Falls, ID 83401

B. R. Dickey

Allied Chemical Corporation

550 - 2nd Street

Idaho Falls, ID 83401

W. J. Godfrey

Allied-General Nuclear Services

P.O. Box 847

Barnwe11, SC 29812
W. J. Price

Allied-General Nuclear

Services

P.O. Box 847

Barnwell, SC 29812

A. Williams

Allied-General Nuclear Services

P.O. Box 847

Barnwel1, SC 29812

M. J. Steindler

Argonne National Laboratory

9700 South Cass Avenue

Argonne, IL 60439

L. Jardine

Argonne National Laboratory

Chemical Engineering Division

Argonne, IL 60439

Bechtel Corporation

50 Beale Street

San Francisco, CA 94119

M. Steinberg

Brookhaven National Laboratory

Research Library

Reference Section

Information Division

Upton, Long Island, N 11973

A. W. Allen

C-E Refractories

P.O. Box 828

Valley Forge, PA 19482

R. Beckman

Combusion Engineering, Inc.

Combustion Division

Windsor, CT 06095

M. G. Britton

Corning Glass Works

Technical Staffs Division

Corning, N 14830

D. L. Ziegler

Dow Chemical Company (ERDA)

Rocky Flats Division

P.O. Box 888

Golden. CO 80401

R. F. Bradley

E. I - duPont DeNemours and Co.

Savannah River Laboratory

Aiken, SC 29801

C. H. Ice

E. I duPont DeNemours and Co. Savannah River Laboratorv

Aiken, SC 29801 
A S. Jennings

E. I. duPont DeNemours and Co. Savannah River Laboratory

Aiken, SC 29801

\section{J. A Kelley}

E I - duPont DeNemours and Co. Savannah River Laboratory Aiken, SC 29801

R. F. Williams

Electric Power Research Institute

3412 Hillview Avenue

P.O. Box 10412

Paio Alto, CA 94304

G. L. Meyer

Environmental Protection Agency

Technology Assessment Division

(AW-559)

Office of Radiation

Programs

Washington, DC 20460

M. F. Browning

Battelle Columbus Laboratories

505 King Avenue

Columbus, OH 43201

S. J. Beard

Exxon

Richland, 99352

L. T. Lakey

Exxon

Richland, WA 99352

M E. Spaeth

Exxon

Richland, 99352

R. G. Barnes

General Electric Company

175 Curtner AVenue

(M/C 160)

San Jose, CA 95125

A Carson

General Electric Company

175 Curtner Avenue

(M/C 160)

San Jose, CA 95125

L. H. Brooks

General Atomic Company

P.O. Box 81608

San Oiego, CA 92138

J. J. Shefcik

General Atomic Company

P.O. Box 81608

San Diego, CA 92138
Central Research Library Document Reference Section

Oak Ridge National Laboratory ( $(\mathrm{RDA})$

P.0. Box X

Oak Ridge, TN 37830

Central Research Library, ORN Oak Ridge National Laboratory (ERDA)

P.O. Box X

Oak Ridge, TN 37830

Laboratory Records Dept., ORN

Oak Ridge National Laboratory (ERDA)

P.O. Box X

Oak Ridge, TN 37830

Laboratory Records Dept., ORNL-RC

Oak Ridge National Laboratory (ERDA)

P.O. Box X

Oak Ridge, TN 37830

C. W. Christenson

Los Alamos Scientific

Laboratory (ERDA)

P.O. Box 1663

Los Alamos, M 87544

J. P. Ouckworth

Plant Manager

Nuclear Fuel Services, Inc.

P.O. Box 124

West Valley, NY 14171

W. Lewis

Vice President

Nuclear Fuel Services, Inc.

6000 Executive Blvd.

Suite 600

Rockville, MD 20852

G. J. Mecarthy

Pennsylvania State University

Materials Research Laboratory

University Park, PA 16802

P. D. O'Brien

Sandia Laboratories

Albuquerque, NM 87107

R. W. Lynch

Sandia Laboratories

Albuquerque, M 87107

W. Weart

Sandia Laboratories

Albuquerque, M 87107
J. 0. Blomeke

Union Carbide Corporation (ORNL)

Chemical Technology Oivision

P.O. Box Y

Oak Ridge, TN 37830

H. W. Godbee

Union Carbide Corporation (ORNL)

Chemical Technology Division

P.O. Box Y

Oak Ridge, TN 37830

C. D. Zerby

Union Carbide Corporation

Office of Waste Isolation

P.O. Box Y

Oak Ridge, TN 37830

\section{FOREIGN}

J. H. C. Castro

Universidade Federal

de Sao Carlos

Departmento de Engenharia

de Materials

13560 Sao Carlos, S.P.

BRAZIL

P. J. Dyne

Atomic Energy of Canada Ltd.

W.N.R.E. Pinawa, Manitoba

ROE 1 LO

CANADA

J. A C. Marples

Atomic Energy Research

Establ ishment

Harwel 1, Didcot, Berks

ENGLAND

D. W. Clelland

United Kingdom Atomic Energy Authority

Risley, ENGLAND

R. Sonniaud

Centre de Marcoule

8. P. 106

30 - Bagnols S/Ceze

PRANCE

R. P. Rand

Bundesministerium für

8ildung und Wessenschaft

D53 Bonn 12

Postfach 120124

GRMANY

$N$ S. Sunder Rajah

Government of India

Bhabha Atomic Research Centre

Hall No. 5

Trombay

Bombay 8S INDIA 
Hans W. Levi

Hahn-Meitner-Institut

1 Berlin 39

Glienickerstr. 100

GEMANY

W. Lutze

Hahn-Meitner-Institut

1 Berlin 39

Glienickerstr. 100

GPIMANY

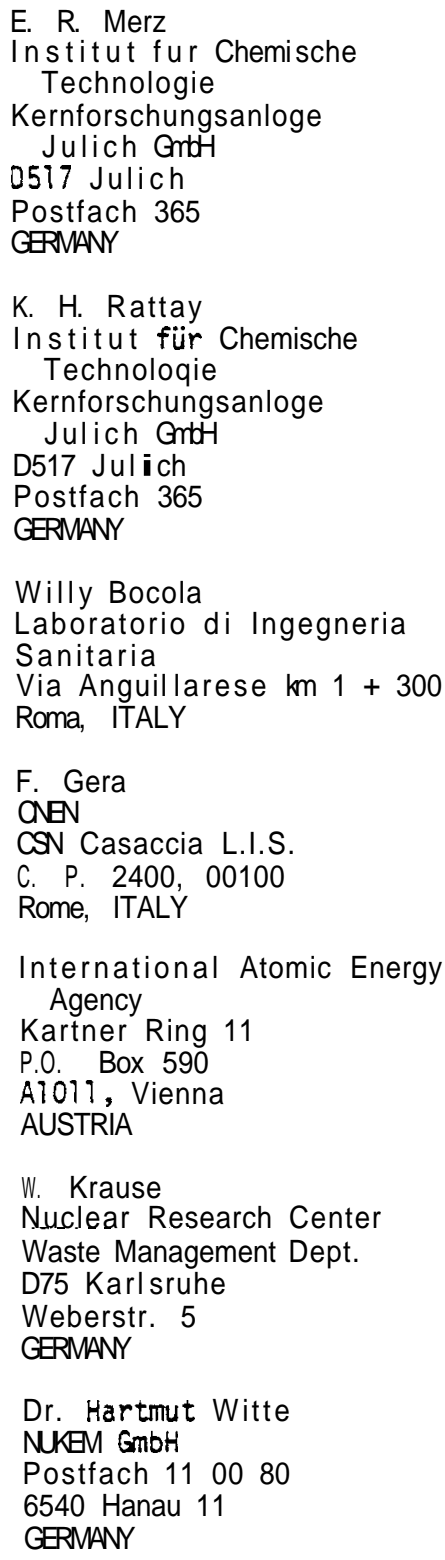

T. Sakakura

Power Research and Nuclear

Fuel Development Division

Reprocessing Division

PNC (1-9-13, Akasaka

Minato-Ku, Tokyo)

JAPAN

Dr. Mrs. Bell

Center for Atomic Energy

Documentation (ZAED)

P.O. Box 3640

7500 Karlsruhe

GRMANY

Bundeministeriurn fiir

Forschung und Techno1ogie

Stresemannstrasse 2

5300 Bonn

GRMANY

KFA-Kernforschungsanlage

Julich GrbH

Postfach 1913

5170 Julich 1

GRMANY

Gesellschaft fur

Wiederaufarbeitung

von Kernbrennstoffen mbH (GWK)

7301 Leopoldshafen

GRMAN

Gesellschaft fir Kernforschung (GfK)

Postfach 3640

7500 Karlsruhe

GRMAN

Dr. H. F. Ramdohr

c/o Friedrich Unde OmbH

46 Durtmund

Degginstre 10-12

GERMNY

\section{ONSITE}

1 GDA Richland Operations Office

W. A Burns

1 EDA Richland Operations Office

Programs Division

1 QRDA Richland Operations Office

Safety and Quality

Assurance Division

$$
\text { J. H. Straub, Director }
$$

6 ADA Richland Operations Office

Production and Waste

Management Program Division
O. L. Elgert
R. B. Goranson
R. D. Fogerson
C. R Palmer
D. J. Squires
F. R Standerfer

15 Atlantic Richfield Hanford Co.
D. $\mathrm{R}$ Gustavson
R. E. Isaacson
10 J. D. Kaser
W. W. Schuiz
J. H. Warren
D. D. Wodrich

2 Hanford Engineering Development Labs

D. G. Ooran

H. H. Yoshikawa

1 Joint Center for Graduate Study

L. C. Olsen

1 Westinghouse Hanford Company

G. L. Richardson

127 Batte?le-Northwest

D. T. Aase

G. S. Allison

T. W. Ambrose

D. G. Atteridge

D. A. Baker

J. W. Bartlett

J. L. Bates

M. A. Bayne

W. J. Bjorklund

H. T. Blair

W. F. Bonner

E. R Bradley

J. L. Brimhall

R. L. Brodzinski

R. J. Brouns

L. R. Bunnell

L. L. Burger

S. H. Bush

J. R Carrel1

N. E. Carter

C. C. Chapman

T. D. Chikalla

R. G. Clark

T. L. Criswell

S. D. Dahlgren

M. T. Dana

D. E. Deonigi 
Battelle-Northwest (Continued)
R. D. Dierks
R. L. Dillon
D. A. Dingee
P. J. Dionne
B. H. Duane
J.W. Finnigan
J. C. Fox
J. J. Fuquay
J. E. Garnier
A. A. Garrett
R. D. Gastil
T. A. Golding
B. F. Gore
M. S. Hanson
J. iv. Hartley
A. J. Haverfield
J. H. Jarrett
U. P. Jenquin
A. 8. Johnson, Jr.
R. H. Jones
T. J. Kabele
Y. B. Katayama
W. S. Kelly
R. S. Kemper
$H$. E. Kissinger
D. A. Kottwitz
N. Laegried
8. R. Leonard, J r
D. L. Lessor
H. B. Liemohn
R. C. Liikala
M. A. Mckinnon
J. L. MCEl roy
R. F. Maness
R. P. Marshall
J. E. Mendel
E. S. Murphy
R. O. Nelson
D. F. Newman
R. E. Nightingale
D. E. Olesen
L. T. Pedersen

R. T. Perry

A. M. Platt

D. R. Pratt

D. L. Prezbindowski

L. A. Rancitelli

j. F. Remark

D. S. Renne

R. E. Rhoads

W. D. Richmond

F.P. Roberts

W. A. Ross

J. M. Rusin

W. F. Sandusky

L. C. Schmid

N. M. Sherer

D. H. Siemens

E. P. Simonen

R. I. Smith

J. K Soldat

C. W. Stewart

K. 8. Stewart

R. W. Stewart

J. A. Strand

D. L. Styris

A. M. Sutey

V. L. Teofilo

G. L. Tingey

M. T. Thomas

R. C. Thompson

L. H. Toburen

T. J. Trapp

R. P. Turcotte

H. H. Van Tuyl

R. Wang

R. E. Westerman

J. H. Westik, Jr.

L. D. Williams

W. K. Winegardner

10 J. R. Young

M. G. Zimmerman

9 Technical Publications (BH) 